Universidade de Brasília (UnB)

Faculdade de Economia, Administração, Contabilidade e Ciência da Informação e Documentação (FACE)

Departamento de Ciência da Informação e Documentação (CID)

Aluno: Fábio Marques Brito da Silva

Bacharelado em Biblioteconomia

O impacto do design emocional na recuperação da informação no catálogo público de acesso em linha 
Fábio Marques Brito da Silva

\title{
O impacto do design emocional na recuperação da informação no catálogo público de acesso em linha
}

\author{
Monografia apresentada ao Departamento de Ciência da \\ Informação e Documentação da Universidade de Brasília \\ como requisito para obtenção do grau de Bacharel em \\ Biblioteconomia.
}

Orientadora: Ivette Kafure

Brasília, 25 de Novembro de 2009. 
Título: O impacto do Design Emocional na recuperação da informação no catálogo público de acesso em linha

Aluno: Fábio Marques Brito da Silva

Monografia apresentada ao Departamento de Ciência da Informação e Documentação da Universidade de Brasília, como parte dos requisitos para obtenção do grau de Bacharel em Biblioteconomia.

Brasília, 25 de novembro de 2009.

Aprovada por:
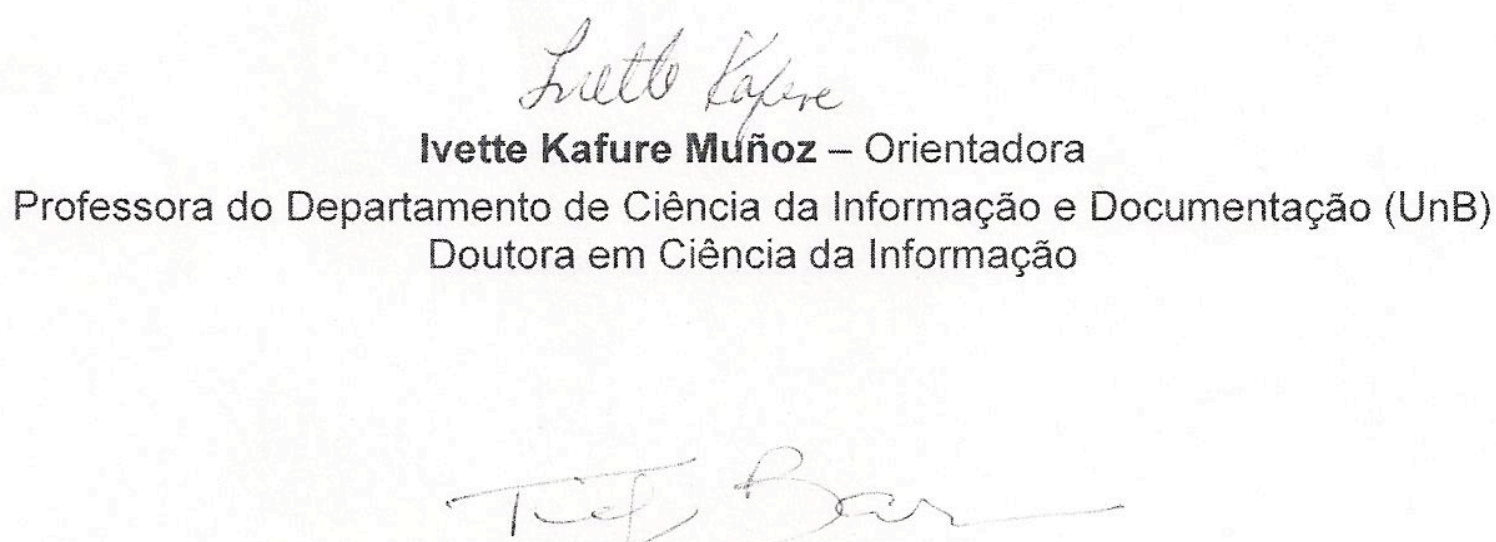

Tiago Barros Pontes e Silva - Membro

Professor do Departamento de Desenho Industrial (UnB)

Mestre em Psicologia
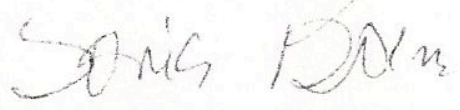

Sonia Araújo de Assis Boeres - Membro

Mestre em Ciência da Informação 


\section{Aos meus pais}




\section{Obrigado}

Aos meus pais e família por acompanharem e incentivarem minha vida acadêmica durante todos estes anos. Além de me darem suporte para construir meu futuro.

Aos amigos por alegrarem e energizarem os meus dias nesta longa jornada de conclusão de curso de graduação.

Aos professores, coordenadores e orientadores por me darem embasamento informacional, teórico, tão relevante para minha futura vida profissional.

Ao Luis companheiro e inspiração de cada dia.

Ao pessoal da secretaria.

À Universidade de Brasília.

A Deus e aos orixás pela vida. 
"O presente é tão grande, não nos afastemos. Não nos afastemos muito, vamos de mãos dadas."

(Carlos Drummond de Andrade) 


\section{Resumo}

O design emocional da informação tornou-se uma preocupação para as ciências que lidam com a organização do conhecimento registrado e com a recuperação da informação, devido à importância das emoções, que sensibilizam os usuários de produtos informacionais, tornando-os receptivos ou não receptivos e influenciando-os na hora da busca. Os catálogos públicos de acesso em linha (OPACs) de bibliotecas, como um desses produtos, normalmente não levam em consideração o design emocional para o desenvolvimento da aparência de suas interfaces, sendo utilizados designs direcionados apenas com a parte funcional. Tendo em vista essa situação, o presente trabalho procurou analisar a interface do OPAC da Biblioteca Central (BCE) da Universidade de Brasília (UnB) levando em consideração os princípios do design emocional, o nível de satisfação dos usuários em relação ao catálogo e apresentar sugestões que podem ser aplicadas à interface para enriquecer a sua interação emocional, por meio de modificações.

Os dados foram coletados em testes e pré-testes, depois dos usuários verem a interface do OPAC e relatarem suas emoções diante dela. Posteriormente, foram analisados, descritos e alguns transformados em recomendações aplicadas a protótipos em papel da interface do OPAC, encontrados no final do trabalho.

Confirmou-se que diante da versão final do protótipo em papel da interface modificado, os estados afetivos dos usuários ficaram melhores, do que diante da interface original do catálogo. Na interface original ficaram, em geral, neutros e diante do protótipo em papel após as modificações, positivos.

Palavras-chave: Design emocional. Recuperação da informação. Catálogo público de acesso em linha (OPAC). 


\begin{abstract}
The emotional design of information has become a concern for the sciences that deal with the organization of recorded knowledge and information retrieval, because of the importance of emotions, which affects users of information products, making them receptive or unreceptive and influencing at the time of the search. The Online Public Access Catalogues (OPACs) of libraries, as one of these products, generally do not consider the emotional design to the development of its interfaces' appearance, using designs, directed solely with the functional part. Given this situation, this study was made to analyze the interface of the OPAC's Central Library (BCE) of the University of Brasília (UnB) considering the principles of emotional design, the level of user's satisfaction in relation to the catalogue and making suggestions that can be applied on the interface to enrich its emotional interaction, through modifications.

Data were collected in pre-tests and tests after the users see the OPAC's interface and report their emotions in front of her. Were subsequently analyzed, described and some were turned into recommendations applied to paper prototypes of OPAC's interface, found at the end of this work.

It was confirmed that the users' affective states in front of the paper prototype's final version of the modified interface were better than the affective states of the users in front of the catalogue's original interface. On the original interface, generally, they were neutrals and on the paper prototype, after the modifications, positives.
\end{abstract}

Key-words: Emotional design. Information retrieval. Online Public Access Catalogue (OPAC). 


\section{Lista de figuras}

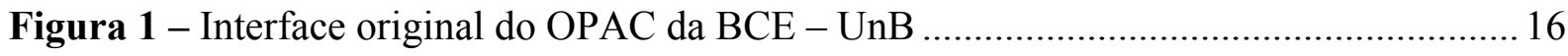

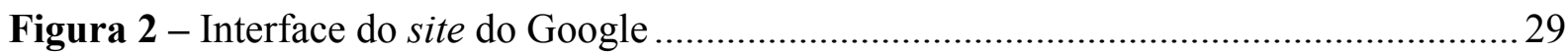

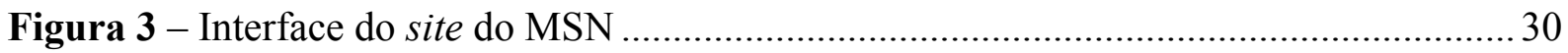




\section{Lista de abreviaturas e siglas}

BCE - Biblioteca Central da UnB

CID - Departamento de Ciência da Informação e Documentação

ISO - International Standard Organization (Organização Internacional de Normalização)

OPAC - Online Public Access Catalogue (Catálogo Público de Acesso em Linha)

UnB - Universidade de Brasília 


\section{Sumário}

\section{1 - Introdução}

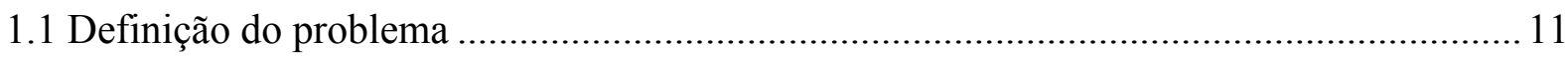

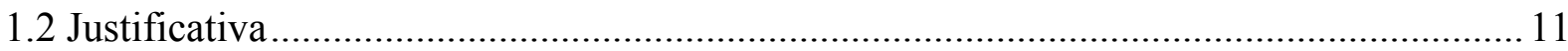

\section{2 - Revisão de Literatura}

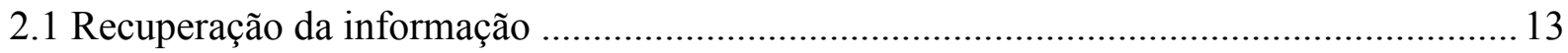

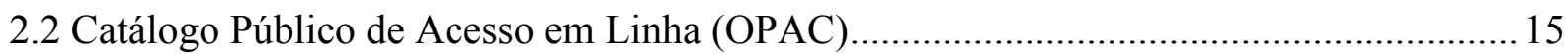

2.3 Design Emocional da Informação no Catálogo Público de Acesso em Linha ..................... 18

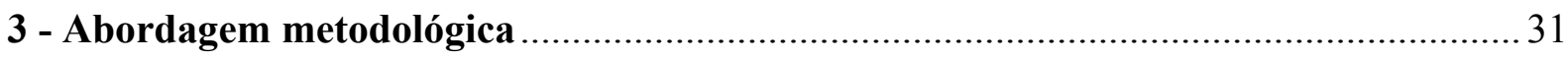

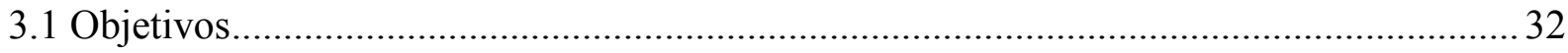

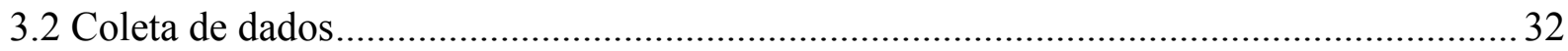

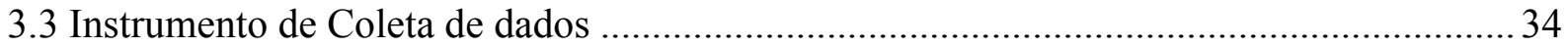

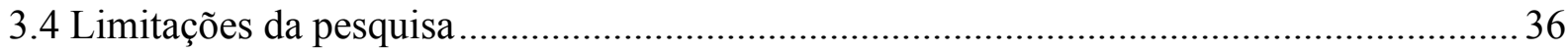

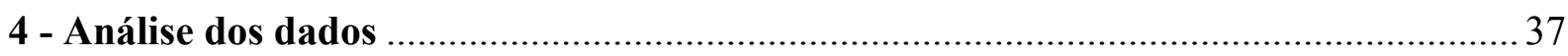

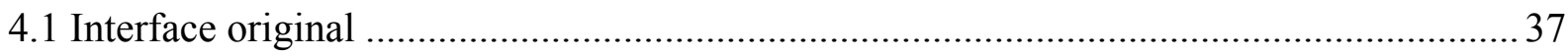

4.2 Versão inicial do protótipo em papel da interface modificada ............................................. 41

4.3 Versão final do protótipo em papel da interface modificada................................................ 45

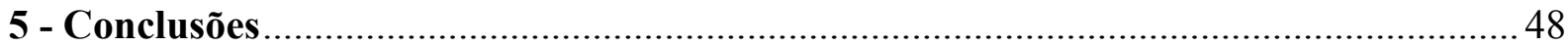

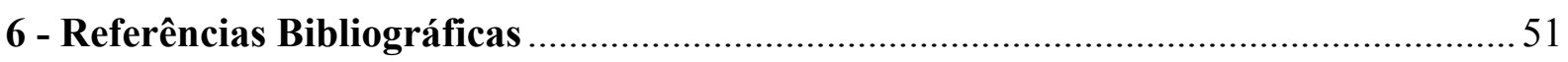

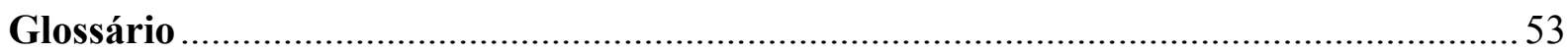

Apêndices

A. Versão inicial do protótipo em papel da interface modificada do OPAC da BCE...............54

B. Versão final do protótipo em papel da interface modificada do OPAC da BCE...................55

C. Questionário final aplicado para a interface original do OPAC …………………………....56

D. Questionário final aplicado para a versão final do protótipo em papel da interface

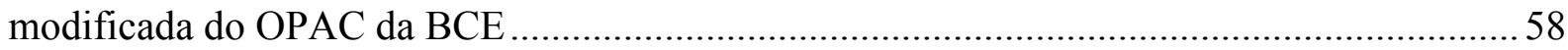

Anexo

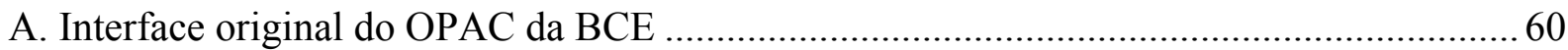




\section{1 - Introdução}

\subsection{Definição do Problema}

No contexto do design emocional aplicado a informação em linha, ela tem um impacto sobre o usuário. Este impacto mexe com ele, faz com que ele se sinta bem, mal, irritado, confuso ou de alguma outra maneira.

Esta pesquisa tem por objetivo geral identificar esse impacto e como ele afeta o usuário do sistema na recuperação da informação. Visto que o foco da ciência da informação é o usuário, o estudo do usuário é fundamental para compreendê-lo melhor e saber suas necessidades e desejos.

Mais especificamente, esta pesquisa pretende responder a seguinte pergunta: qual o impacto que o design emocional da informação da homepage (página de abertura) de um catálogo público de acesso em linha tem no usuário no momento em que busca recuperar informação? Para sugerir uma maneira de construir uma interface emocionalmente positiva e satisfatória, centrada em princípios de design emocional e usabilidade. A usabilidade pode ser definida de acordo com a Norma ISO 9241 como: a capacidade que apresenta um sistema interativo de ser operado de maneira eficaz, eficiente e agradável, em um determinado contexto de operação, para a realização das tarefas de seus usuários (ISO 9241-11, 1994).

\subsection{Justificativa}

É visível que o design emocional da informação influencia o usuário no momento de sua busca nos catálogos em linha. Informações bem editoradas, estruturadas, divertidas, coloridas nas páginas desses catálogos tornam fácil a sua recuperação, motivam a pesquisa. Enquanto que informações rígidas, monocromáticas, estruturadas, editoradas, ao acaso, ou sem um padrão ou estudo de usuários prévio, dificultam o encontro da informação desejada e podem desmotivar a pesquisa (NORMAN, 2008). 
No momento da pesquisa no OPAC é importante que a interface seja de uma cor agradável, que seja "limpa", com pouca poluição visual, evitando assim o excesso de informação ao usuário e o cansaço visual, para que ele se mantenha motivado a utilizá-lo. Araújo (1986, p. 402) citado por Hoeltz (2001, p.3) já destaca a importância da estruturação das páginas discorrendo sobre o que chama de princípio de legibilidade:

Em sentido restrito, essa legibilidade depende da maneira como se dispõem os caracteres (em palavras, frases, períodos) nas linhas, tornando a leitura cômoda ou, ao contrário, às vezes impraticável; em amplo sentido, porém, tal disposição deve combinar-se à própria organização da página, vale dizer, o modo como se articulam nesse espaço os elementos que o conformam em um todo, em uma unidade (ARAÚJO, 1986, p. 402 apud HOELTZ, 2001, p. 3).

As informações básicas das funcionalidades de um catálogo também devem estar dispostas de tal forma que seja fácil encontrá-las e mais interessante ainda se forem divertidas de usar.

Portanto, o tema a ser retratado neste trabalho monográfico é relevante porque pretende investigar e descrever se o usuário está satisfeito com as interfaces dos catálogos em linha das bibliotecas, assim como contribuir para que essas possam enriquecer ou aperfeiçoar suas interfaces, melhorando a editoração das páginas desses catálogos e a sensação dos usuários diante da tela, com base em princípios do design emocional da informação. 


\section{2 - Revisão de Literatura}

\subsection{Recuperação da informação}

No século XXI, marcado pela enorme quantidade de informações, tanto em meio impresso como em meio virtual, sistemas de recuperação da informação se fazem cada vez mais necessários para sua rápida e precisa localização. A finalidade é aumentar a qualidade de vida dos usuários de biblioteca ou de unidades de informação quaisquer.

A recuperação da informação, em seu sentido mais geral, é o processo de procurar documentos que estão armazenados em um espaço, com a finalidade de acessá-los e satisfazer as necessidades informacionais dos usuários.

Pignatari (1977, p. 45) relaciona a informação com seleção e escolha, conceituando-a como instruções seletivas. Para ele, só existe informação quando existem dúvidas e isso pressupõe um conjunto de alternativas, dentre as quais uma ou várias reduzem ou eliminam o duvidoso. Dito de outra forma, informação para Pignatari é a redução do incerto. A recuperação da informação está intimamente relacionada a essa definição, possibilitando ao usuário satisfazer suas necessidades, dúvidas ou anseios.

Rowley (2002) explica que os sistemas de recuperação da informação já foram confundidos com computadores, ou seja, somente sistemas virtuais, mas que sistemas de recuperação em papel ainda existem e vieram muito antes da informática surgir. A autora ainda estabelece que todos os sistemas de recuperação da informação podem ser entendidos como formados por três etapas: indexação, armazenamento e recuperação.

A indexação envolve a atribuição de termos ou códigos para um documento, que visam a sua posterior recuperação. O armazenamento pode ser físico, em estantes, ou virtual, em bases de dados de computadores. A recuperação em si depende bastante dessas duas etapas anteriores.

Rowley (2002) estabelece ainda que a importância dos computadores não deve ser subestimada na recuperação da informação, já que as consultas em linha, ou seja, as recuperações em linha, possibilitam uma flexibilidade que seria impraticável em sistemas em papel. Esta afirmação, provavelmente, está associada com a maior facilidade e rapidez com que o usuário pode recuperar um documento em linha, que recuperá-lo em papel. 
Visto que o presente trabalho monográfico disserta a respeito do universo do catálogo público de acesso em linha, visou-se enfatizar a recuperação em linha em vez de recuperação em papel.

No contexto das bases de dados a recuperação é composta por três etapas (Rowley, 2002, p. 163 - interpretação própria):

A. representação de sua necessidade de informação, com a formulação de uma linguagem de consulta, linguagem própria do usuário;

B. comparação pelo sistema da linguagem própria do usuário e da linguagem de cada um dos documentos da base;

C. geração de um resultado de busca com a recuperação de registros baseados nessa comparação.

Segundo a autora muitos usuários passam por essas três etapas antes de encontrar uma informação. Nesse ponto, percebe-se a importância da intermediação do profissional da informação, pois é ele que geralmente domina as linguagens dos documentos e pode ajudar o usuário em suas buscas por informação.

O usuário pode ter conhecimentos limitados sobre o universo da pesquisa por informações e pouca experiência com a formalidade das linguagens que representam os documentos - linguagens que supostamente foram construídas para facilitar a comunicação do usuário com um sistema de recuperação (CINTRA, 1994).

Dessa maneira, o profissional da informação pode auxiliar na elaboração de melhores estratégias de busca e solucionar as dúvidas, por meio do serviço de referência em uma biblioteca, de serviços de informação em uma instituição ou virtualmente.

Os mecanismos para recuperar a informação podem auxiliar o usuário em sua busca, tornando-a mais efetiva e rápida. Mooers (1951) citado por Saracevic (1996, p. 25) já anunciava tal importância ao caracterizar a recuperação da informação: "engloba os aspectos intelectuais da descrição de informações e suas especificidades para a busca, além de quaisquer sistemas, técnicas ou máquinas empregados para o desempenho da operação".

Exemplos de tais mecanismos são os tutoriais, os tesauros, os vocabulários controlados, os operadores booleanos, entre outros.

Os tutoriais em linha, espécie de tira dúvidas sobre algum tema, contêm dicas e orientações de como operar a base de dados ou o sistema de recuperação de informações, com informações sobre como fazer determinada tarefa, como uma pesquisa avançada, por exemplo. 
Os tesauros, forma de estrutura hierárquica de termos sobre determinada área do conhecimento, orientam os usuários quanto aos termos mais adequados e precisos ou genéricos para a sua pesquisa.

Os vocabulários controlados são um conjunto preciso de vocábulos utilizados para representar (indexação) ou recuperar informações, como listas alfabéticas de termos autorizados de uma biblioteca que podem auxiliar o usuário, fazendo com que ele utilize uma linguagem de pesquisa mais próxima à linguagem dos documentos e não de sua linguagem natural (CINTRA, 1994). Em conseqüência disso, aumentando a precisão das informações recuperadas.

Os operadores booleanos, termos que permitem refinar (por exemplo, o "not") ou ampliar (por exemplo, o "and") a pesquisa também são importantes no momento das pesquisas, pois auxiliam ao usuário e facilitam uma recuperação da informação mais rápida, permitindo, por exemplo, a busca por dois assuntos ao mesmo tempo.

Existem outros mecanismos que auxiliam ao usuário no momento da recuperação da informação, no entanto, optou-se por apenas citá-los, por serem menos comuns para os usuários de sistemas em linha. É o caso dos sistemas de classificação, dos cabeçalhos de assuntos, entre outros.

Variados tipos de sistemas de recuperação de informações existem: os serviços de buscas em linha ou motores de busca, o cederrom, a própria internet, os catálogos públicos de acesso em linha, os sistemas de gerenciamento de documentos (ROWLEY, 2002).

Todos com um objetivo em comum, o usuário: "O objetivo de qualquer sistema de recuperação da informação é ser usado pelo grupo de pessoas para as quais foi projetado" (ROWLEY, 2002, p. 181). Cabe complementar e ressaltar aqui que o objetivo não é somente o uso, mas também produzir nos usuários emoções positivas, as quais serão retratadas no tópico 2.3, relativo ao design emocional da informação.

O presente trabalho acadêmico optou por centrar-se apenas em um tipo de sistema de recuperação: o catálogo público de acesso em linha ou Online Public Access Catalogue (OPAC), que será o próximo item desta revisão de literatura.

\subsection{Catálogo Público de Acesso em Linha (OPAC)}

O catálogo público de acesso em linha ou Online Public Access Catalogue (OPAC) é realidade em um número cada vez maior de bibliotecas. Bibliotecas públicas, universitárias, 
especializadas, entre outras, têm utilizado os recursos da internet para disponibilizar seus OPACs e mostrar ao mundo seus conhecimentos registrados.

A figura seguinte mostra a página de abertura de um OPAC:

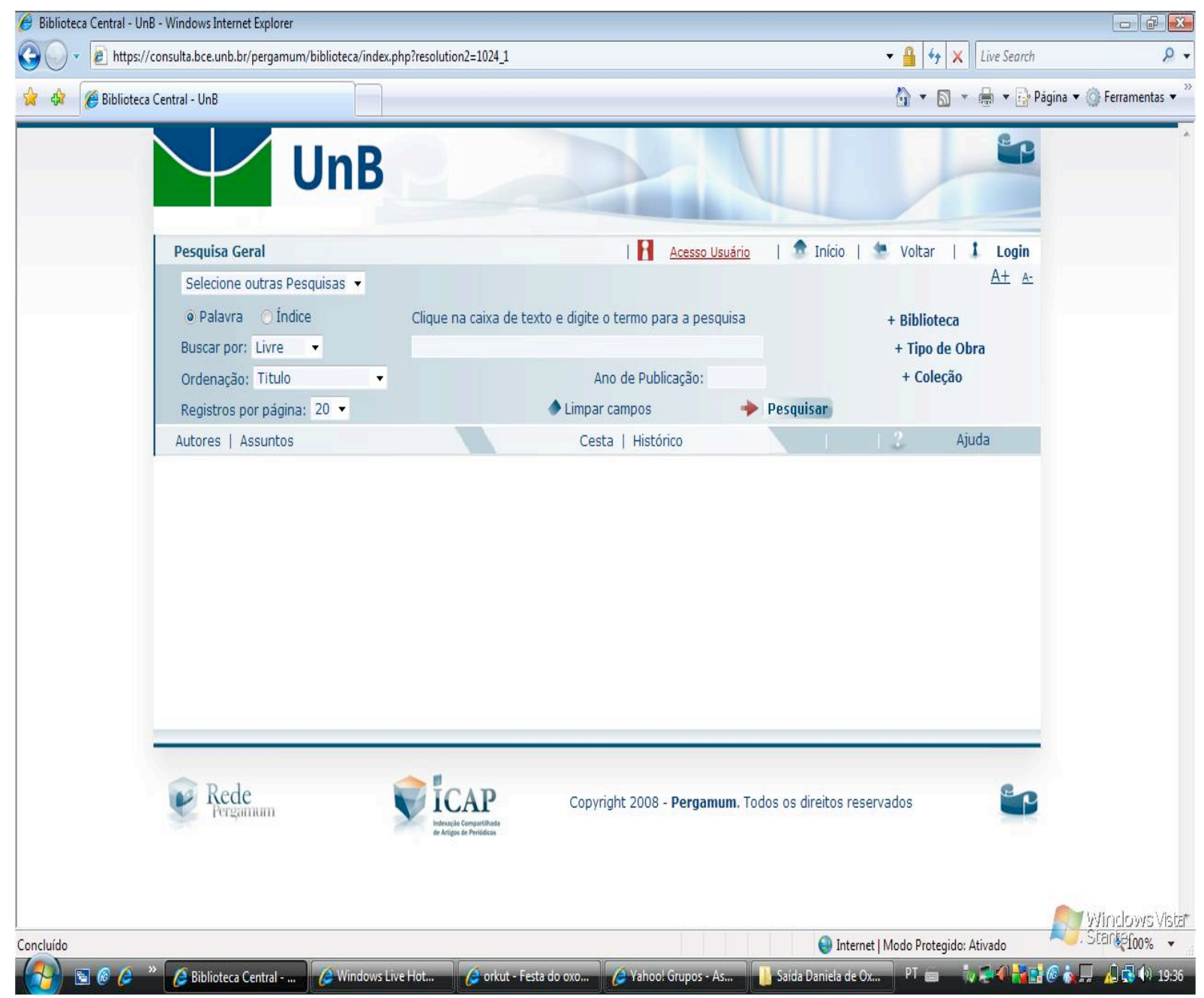

Figura 1 - Interface original do OPAC da BCE - UnB

Fonte: http://www.bce.unb.br

O desenvolvimento tecnológico permitiu que o catálogo tradicional em fichas fosse substituído por um catálogo em formato eletrônico de acesso pela rede mundial de computadores, o OPAC.

A sigla OPAC é normalmente a mais utilizada para se falar de tais catálogos, porque se tornou comum seu uso no Brasil. Provavelmente, pelo costume do país de utilizar palavras estrangeiras em seu vocabulário, ou seja, pelo uso freqüente de estrangeirismos e por ser uma forma mais curta e já conhecida por vários países de se apresentar os catálogos em linha. 
Basicamente os OPACs, assim como qualquer catálogo, são ferramentas de recuperação da informação ou sistemas que servem primordialmente ao registro, organização, recuperação e controle de recursos. No caso das bibliotecas, controle de recursos de informação, em suas coleções.

Em outras palavras os catálogos também podem ser considerados como um meio de comunicação que informa aos usuários o que a biblioteca possui, descrevendo esses itens de forma codificada e organizada, reunidos conforme semelhanças (MEY, 1995).

Uma das vantagens do catálogo em linha sobre o catálogo tradicional é a rapidez com que os registros e as informações contidas no OPAC como um todo podem ser inseridos, alterados e atualizados conforme as exigências de cada biblioteca.

Outra vantagem é a ampliação do acesso, o acesso ilimitado. Visto que o OPAC pode ser acessado de qualquer local com internet ou na própria biblioteca, a qualquer hora e dia, não restringindo, assim, seu uso a determinado espaço físico ou temporal.

A diminuição de custos com papel é outro ponto positivo, pois com uma ferramenta de recuperação em linha não são gastos tantos recursos financeiros com fichas catalográficas ou com papel, como em um catálogo tradicional.

O intercâmbio de informações entre bibliotecas também é facilitado porque as mesmas podem ter informações umas das outras, por meio da internet. Menos trabalho e dinheiro, então, são gastos com serviços como a catalogação, por exemplo. A duplicação de serviços é evitada, facilitando dessa maneira o trabalho entre redes de bibliotecas.

Por fim, a busca e a recuperação da informação são bastante facilitadas, já que o OPAC permite variados tipos de pesquisa, como a pesquisa básica ou a avançada, e por ser automatizado e não manual, aumenta a rapidez com que se encontra a informação.

O catálogo em linha se tornou um aliado dos usuários em suas pesquisas, tendo em vista que a internet disponibiliza um enorme número de informações e documentos, mas não os indexa - representa seus assuntos com o uso de termos - de forma controlada como em catálogo, onde profissionais especializados indexam, armazenam e podem recuperar eficazmente e eficientemente informações registradas.

Rowley (2002) já revela tal eficiência ao dissertar sobre ferramentas de busca:

Uma vez que as ferramentas de busca precisam oferecer acesso a um enorme acervo de documentos, disperso em vários lugares, o processo de recuperação deve ser eficiente. Essa eficiência é obtida pelas ferramentas de busca que atuam com uma representação ou registro do documento e não com a fonte original (ROWLEY, 2002, p. 193). 
As buscas e recuperações na internet podem ser tão confusas e difíceis, que os OPACs se diferenciam como sistemas especializados para recuperação de informações porque são feitos por profissionais que lidam com elas diariamente. Apesar dos OPACs recuperarem, em sua maioria, apenas registros de documentos, há garantia de que esses documentos existem e estão naquele acervo, podendo ser usados de diversas formas.

O OPAC é um mecanismo de busca em linha e os "mecanismos de busca são ferramentas de recuperação que executam o trabalho básico de recuperação, a aceitação da consulta, o cotejo desta com cada um dos registros existentes na base de dados, bem como a apresentação, resultante disso, de um conjunto de itens recuperados" (ROWLEY, 2002, p. 193). Vale lembrar, que são mecanismos de bibliotecas, portanto as buscas são nos acervos das mesmas ou de outras bibliotecas parceiras ou consorciadas.

É importante também que as interfaces do OPAC sejam amigáveis, interativas, e até divertidas para que façam o usuário se sentir bem ao utilizá-las, caso contrário, ele não se sentirá motivado a pesquisar no catálogo, pesquisando somente o estritamente necessário.

Interfaces bem elaboradas, que causem sensações positivas nos usuários e mexam com seu lado emocional os fazem lembrar com carinho do catálogo, associando-o a coisas boas e aumentando, conseqüentemente, seu uso e o nível de satisfação dos usuários diante dele. Princípios de design são fundamentais para tal anseio.

Devido a isso, escolheu-se o design emocional da informação como tópico seguinte desta revisão de literatura para alertar bibliotecas e bibliotecários da relevância de se estudar a emoção como fator importante no contexto biblioteconômico.

\subsection{Design Emocional da Informação no Catálogo Público de Acesso em Linha (OPAC)}

O design emocional aborda a emoção a partir da ótica do design de produtos. Como as pessoas se sentem ao utilizá-los. Nesta revisão de literatura procurou-se aplicar o arcabouço teórico desta área ao produto e objeto principal da ciência da informação: a informação. Para delimitar mais um pouco o universo da pesquisa, foi escolhida a informação no catálogo público de acesso em linha ou Online Public Access Catalogue (OPAC).

Os usuários da informação estão o tempo todo interagindo com produtos, quer seja em suas casas, trabalho ou na própria Unidade de Informação a que pertençam. Catálogos 
impressos, catálogos em linha, livros, periódicos, mesas, computadores entre outros são exemplos de objetos com os quais eles interagem.

O contato com esses objetos causa nos usuários uma sensação, seja ela boa, ruim, de amor ou de ódio, de satisfação ou de insatisfação, alegria ou tristeza, que mostra a presença da emoção, mesmo no contexto da biblioteconomia, diante da interação com produtos. Além da aparência da forma percebida por meio dos sentidos (audição, visão, tato, olfato, paladar), os objetos possuem uma representação diante da sociedade, um significado social e também um significado simbólico próprio, para a pessoa que o possui ou o utiliza.

Exemplificando: a aparência do OPAC vai causar na pessoa que o utiliza um impacto, uma sensação, uma emoção. Além disso, para a sociedade esse OPAC vai ter um significado, geralmente ser um instrumento de pesquisa e para a pessoa que o está utilizando terá um significado próprio, que pode estar associado à emoção sentida naquele primeiro contato visual com a página.

O design emocional considera exatamente esta emoção que os produtos causam nos indivíduos para projetar, construir, aperfeiçoar objetos. Torna-se então essencial compreender melhor a emoção. Segundo Norman (2008): "uma das maneiras pelas quais as emoções trabalham é por meio de substâncias químicas neuroativas que penetram determinados centros cerebrais e modificam a percepção, o comportamento e os parâmetros de pensamento". Logo, a emoção é relevante porque pode modificar o pensamento, o modo de perceber e o comportamento do usuário diante de uma interface de um catálogo, influenciando sua pesquisa e recuperação da informação.

Para os cientistas cognitivos em geral, a emoção está junto da cognição, ela faz parte do modo de conhecer as coisas ao redor, permitindo a formulação de opiniões, valores, idéias. Norman (2008) ainda vai mais longe ao dizer: "de fato a emoção torna você inteligente", o que parece ser um pouco contraditório na vida prática em sociedade, já que se posiciona o conhecimento muito mais próximo à razão do que à emoção.

A própria prática bibliotecária raramente considera o enfoque emocional para a elaboração do design gráfico da interface de seus catálogos públicos de acesso em linha, esquecendo-se que esse enfoque pode alterar toda a impressão, comportamento, sensação do usuário diante delas.

Estudioso da emoção Norman teoriza que ela pode ser mais relevante para que as pessoas gostem de um produto do que seus componentes reais. E estrutura o pensamento humano sobre três diferentes níveis. Esses níveis são visceral, comportamental e reflexivo. 
O visceral é automático ou pré-programado, faz julgamentos rápidos - como o que é bom ou ruim, seguro ou perigoso [...]. O nível comportamental refere-se aos processos cerebrais que controlam a maior parte de nossas ações - como andar de bicicleta, tocar um instrumento musical, dirigir um carro [...]. O nível reflexivo refere-se à interpretação, compreensão e raciocínio e à parte contemplativa do cérebro. É nele que são processadas ações como apreciar uma obra de arte, sentir saudades de um amigo, torcer para um time de futebol (Norman, 2008, p. 14).

Os três níveis do pensamento estão interligados e podem ser percebidos nas relações das pessoas com os objetos. Norman (2008) associa esses níveis ao que nomeia de três níveis de design. Basicamente, o design visceral está relacionado ao primeiro contato que se tem com um produto, às aparências dele, percebidas pelos sentidos, o impacto que se tem ao vê-lo, tocá-lo. O design comportamental está relacionado com a usabilidade, o prazer, a facilidade que se tem ao utilizar um produto e o design reflexivo relacionado com as interpretações, as particularidades de cada indivíduo diante de um produto.

Aplicando esses níveis ao design gráfico da informação na interface de um OPAC, o primeiro impacto do usuário com a aparência da tela, seria resultado de seu design visceral. As relações com a usabilidade de um catálogo, a facilidade de utilizá-lo, seria resultado de seu design comportamental. E as análises, associações ou relações que o usuário faz na interação com a interface, por exemplo, se as imagens ou as informações presentes o fazem lembrar alguma data ou alguém, seria resultado de seu design reflexivo.

Cabe ressaltar, que os conceitos apresentados serão importantes durante todo este trabalho para sua compreensão e análise do impacto emocional da informação nos OPACs.

Os objetos não apenas representam bens materiais e financeiros para quem os utilizam, mas constituem também valores, trazem significados para o usuário (NORMAN, 2008). Os catálogos a partir desse pensamento deixariam de ser meros instrumentos de busca e recuperação da informação e passariam a ser amigos do usuário, aliados no vasto e, por vezes, obscuro mundo da informação eletrônica. Um local onde se pode encontrar informação segura, de fonte confiável, e de forma rápida. Com uma interface interativa, divertida, descontraída, apesar do rigor e cientificidade da informação em seu interior.

Os OPACs deveriam agradar ao usuário tanto no nível visceral, no nível comportamental, como no nível reflexivo. Porém convêm caracterizar que o trabalho pretende focar-se no nível visceral de pensamento, o que não significa que deixará de envolver os demais níveis.

No entanto, o que se percebe nos OPACs em geral é uma ênfase com o design comportamental, com a função dos catálogos, ficando seu design visceral e reflexivo pouco 
trabalhado. Assim, não é de se estranhar que muitas pessoas não considerem que um OPAC precise ser bonito ou exija interpretação, reflexão. Por vezes, o design visceral de suas interfaces pode até causar emoções negativas e, subconscientemente, fazer o usuário não querer utilizá-las, ficar tenso ou até mesmo detestá-las.

"É claro que utilidade e usabilidade são importantes, mas sem diversão e prazer, alegria e entusiasmo [...] nossas vidas seriam incompletas" (NORMAN, 2008, p. 28).

O senso comum crê que as decisões são fruto apenas do pensamento racional e lógico, no entanto o sistema afetivo e as emoções são participantes da tomada de decisões, nos auxiliando a tomar decisões rápidas e mexendo inclusive com nossos sistemas corporais.

No contexto biblioteconômico, o excesso de informações em um OPAC pode deixar o pesquisador tenso, irritado, fazendo com que os músculos de seu corpo fiquem rijos, contraídos. Provocando nele, primeiramente, reações emocionais, viscerais e comportamentais negativas para que somente depois provoque reflexão e sua reação cognitiva, relacionada à forma como ele compreenderá, interpretará a situação.

Fica claro aqui que o sistema emocional pode influenciar o sistema cognitivo. Os estados afetivos diante do contato com um produto podem ser realmente decisivos para o sucesso ou insucesso dele. Esses estados podem ser positivo, negativo ou neutro (eles serão utilizados posteriormente na análise de dados no tópico 4) e são influenciados pelo design emocional dos produtos ou objetos.

O estado afetivo positivo é aquele que deixa as pessoas descontraídas, felizes e bem receptivas com as características de um produto, seja ele bom ou ruim, visto que pessoas sensibilizadas positivamente não dão tanta importância aos detalhes. Esse estado é causado geralmente por produtos com design emocional bem elaborado, dependendo do produto e seu objetivo.

Os estados afetivos negativos e neutros são aqueles que deixam as pessoas atentas, ligadas, concentradas nos detalhes e características dos produtos. Sensibilizam as pessoas negativamente ou não as sensibilizam de nenhuma forma. Esses estados afetivos são causados por produtos com design emocional classificado como normal (neutro), simples, ou ruim (negativo), insatisfatório (também depende do produto e do seu objetivo).

Isen (1993) já mostrou por meio de suas pesquisas sobre o afeto positivo e a tomada de decisões que pessoas que estão mais relaxadas e felizes, expandem sua imaginação, sua criatividade, buscam mais alternativas, mais meios para realizar sua tarefa. E mesmo que tenham algumas dificuldades iram tolerá-las, relevá-las, pois estão felizes. 
Assim, um OPAC com aparência agradável, bonito que cause essa sensação positiva nos usuários, faz com que eles fiquem felizes, relaxados e explorem mais a sua interface a fim de encontrar a informação que desejam recuperar. E mesmo que tenham pequenas dificuldades, não iram se importar tanto, porque estão alegres, bem. É visível, portanto, o destaque do design visceral.

Ao contrário, OPACs com aparência desagradável, perturbadora, causarão sensações negativas nos usuários, deixando-os tensos, nervosos, tristes. Isso fará com que eles se tornem extremamente detalhistas e caso haja dificuldades, essas dificuldades tornar-se-ão grandes problemas, alvo de reclamações e serão sempre lembradas.

Um estado afetivo positivo provocado pelo OPAC no usuário, apesar de permitir mais interrupções, é muito importante para melhorar a interação entre este e aquele. Um usuário com afeto positivo diante de uma interface fica mais curioso, criativo, pronto para aprender e até a esquecer pequenos problemas se ela for divertida de usar.

Para agradar um usuário com afeto negativo causado devido ao impacto com a interface, os seus projetistas terão que estar muito mais atentos aos detalhes, pois este usuário está focado neles enquanto que o usuário com afeto positivo irá relevá-los.

É importante caracterizar que o nível visceral de pensamento é mais primitivo, analisa o OPAC e responde rapidamente ao impacto da interface e o comportamental responderá diante do uso efetivo do catálogo, diante dos sentimentos que acompanham esse uso. Ambos são inconscientes. Enquanto o reflexivo é consciente e responderá com a reflexão e interpretação da página pelo usuário. Os componentes cognitivos do pensamento atribuirão significado e os componentes afetivos, valor (NORMAN, 2008).

O nível visceral de pensamento do homem conquanto seja a parte mais primitiva, responde a uma quantidade grande de condições geneticamente determinadas, as quais são reconhecidas por meio dos sentidos. Ele é incapaz de raciocinar, de comparar uma situação com a história anterior e está programado geneticamente para responder com afeto positivo às seguintes condições (NORMAN, 2008, p. 50):

- lugares aquecidos e bem iluminados;

- clima temperado;

- sabores e odores doces;

- cores alegres, de matizes intensamente saturados;

- sons tranqüilizadores e melodias e ritmos simples;

- música e sons harmoniosos;

- carícias; 
- rostos sorridentes;

- cadências ritmadas;

- pessoas atraentes;

- objetos simétricos;

- objetos lisos e arredondados; e,

- sensações, sons e formas sensuais.

Dentro deste contexto evolutivo da psicologia, adaptando essas condições sistematizadas por Norman ao contexto da interface dos OPACs, interfaces que causariam afeto positivo teriam que oferecer algumas das seguintes condições:

- cores alegres, primárias, intensas, como as encontradas na natureza, em tons que não atrapalhem a visualização;

- ser simétricas;

- possuir elementos gráficos planos e de formas arredondadas;

- imagens, figuras, informações atraentes, alegres, positivas;

- interfaces "iluminadas", claras; e,

- trabalhar com sons harmoniosos, tranqüilos.

Todas essas características seriam positivas para o nível visceral, além delas poder-seia trabalhar com o design reflexivo, usando imagens, figuras ou textos que remetessem a idéias de clima temperado, sabores e odores doces, lugares aquecidos, rostos sorridentes, entre outros.

O nível visceral do pensamento, também está programado geneticamente para responder com afeto negativo automático às seguintes condições (NORMAN, 2008, p. 50):

- alturas;

- $\quad$ sons altos ou luzes muito intensas, súbitos e inesperados;

- objetos indistintos pairando no ar (objetos que parecem estar prestes a bater no observador);

- calor ou frio extremos;

- escuridão;

- luzes extremamente fortes ou sons extremamente altos;

- terreno plano, vazio (desertos);

- terreno denso, atravancado (selva ou florestas);

- multidões de pessoas; 
- cheiros de podridão, alimentos em decomposição;

- sabores amargos;

- objetos pontiagudos;

- $\quad$ sons estridentes abruptos; entre outros.

Adaptando-as ao design visceral da interface dos OPACs eles, para evitar afeto negativo nos usuários, deveriam evitar:

- deformações ou estruturas não simétricas;

- $\quad$ sons estridentes ou não harmoniosos;

- imagens, figuras pontiagudas;

- grandes espaços vazios na tela;

- excesso de informações; e,

- cores muito escuras ou extremamente fortes.

Além disso, no design reflexivo da interface do OPAC, dever-se-ia evitar imagens que remetessem os usuários a qualquer uma das condições negativas mostradas anteriormente.

Apesar dessas concepções gerais do que é universalmente positivo ou negativo visceralmente, não existem regras quando se lida com emoções. Até porque não há somente um nível de pensamento no cérebro humano. E como Norman (2008) relata, os três níveis estão interligados, não funcionam sozinhos. As interfaces nunca conseguiram ser atraentes ou positivas para todo mundo.

As relações emocionais de fato são fruto de interação prolongada com um produto. Logo, o usuário de um catálogo público de acesso em linha somente por meio de atração visceral não desenvolverá esse tipo de relação, porque ela envolve um tempo presente, o agora. O nível reflexivo mostra-se essencial para isso, por ser de longa duração e por fazer com que o usuário associe algo de sua vida, algum acontecimento, com a página.

Então, por exemplo, se a página do catálogo contém alguma imagem ou informação que o faz lembrar-se de alguém ou associar aquela imagem a algo importante em sua vida, ele irá ter uma relação duradoura com o OPAC, porque sempre que acessá-lo essa lembrança ou associação vai acontecer.

“Objetos especiais se revelaram ser aqueles com recordações ou associações especiais, aqueles que ajudavam a evocar um sentimento especial [...]" (NORMAN, 2008, p. 68). O inverso igualmente é verdadeiro, já que associações ou recordações ruins da página afastariam o usuário. 
Associar o OPAC a pessoas inteligentes, famosas, pesquisadores de mérito ou professores queridos pelos alunos, ou qualquer outra coisa que passasse uma imagem boa do catálogo ao seu público alvo, daria a ele também destaque especial na vida do usuário. Tudo porque mexe com a sua emoção, dá-lhe orgulho de usar o OPAC. O marketing também está envolvido no design emocional da informação.

Estilos simples ainda predominam em muitos objetos, como é o caso de muitas interfaces de catálogos, mas "Objetos atraentes, de fato, funcionam melhor - atratividade produz emoções positivas, fazendo com que os processos mentais sejam mais criativos, mais tolerantes diante de pequenas dificuldades" (NORMAN, 2008, p. 82).

Convém nesta parte da pesquisa sustentar a importância do design visceral, por ser o seu propósito principal.

Segundo Norman (2008), O design visceral é o que está presente no meio ambiente, o que se vê no dia-a-dia, os elementos da natureza. Em função disso, o homem já é préprogramado a captar os sinais emocionais que vêm dela. Todo o processo evolutivo fez com que as flores, as frutas, os animais se tornassem mais atraentes como parte do mecanismo de sobrevivência, disseminação. Frutas e flores tendem a ser simétricas, arredondadas, lisas, agradáveis ao toque e coloridas. Flores possuem cheiros agradáveis, frutas, em sua maioria, sabor doce. Tudo isso com a função de atrair seres vivos. Essa seria a explicação do homem gostar de sabores e cheiros doces, cores fortes, claras, alegres, saturadas e preferirem objetos e corpos simétricos. E de todos eles estarem associados ao prazer.

A explicação do gosto pelo amargo, pelo barulho excessivo, por locais muito cheios, entre outros visceralmente negativos somente é possível porque o nível reflexivo age se sobrepondo e causando experiências reflexivamente positivas. Em outras palavras a pessoa por meio da reflexão, do raciocínio, consegue driblar suas predisposições geneticamente determinadas.

Seguindo a mesma linha de raciocínio, mas aplicada aqui à informação, em geral, a interface de um OPAC que siga os princípios mostrados do design visceral será atraente e causará, por conseqüência, impacto positivo em seus usuários. Cabendo ao design comportamental e reflexivo manter esse impacto.

As reações iniciais de um pesquisador em frente a um catálogo merecem destaque, afinal, um pesquisador assustado, impactado negativamente, irritado, não vai querer utilizar o catálogo novamente, pois a sua impressão da página será negativa. A aparência do OPAC importa. Ela faz diferença na avaliação de um instrumento, mesmo que seja um instrumento 
de busca e recuperação de informação. Essa diferença é subconsciente, por isso não é valorizada pelo usuário que pensa que a estética não vai influir em nada em sua busca.

O aspecto reflexivo, é claro, entra no processo avaliativo do catálogo por conseqüência, visto que é a reflexão que permite compreender o impacto geral dele na vida do usuário e o processo avaliativo do OPAC como um todo. O homem não é somente composto por reações viscerais ou instintivas, é acima de tudo composto por reflexão, interpretação, raciocínio. Esses níveis interagem sempre.

Eles são tão importantes que podem até mesmo anular o nível comportamental. É o caso a seguir, em que o consumidor comprou um espremedor de laranja de ouro e não pode usá-lo por que o estragaria.

“Comprei um espremedor caro, mas não posso usá-lo para fazer suco! Nota zero para o design comportamental. E daí? Orgulhosamente, exibo o espremedor no saguão de minha casa. Nota cem para a atração visceral. Nota cem para a atração reflexiva" (NORMAN, 2008, p. 15).

O objetivo aqui não é hiper valorizar o visceral e o reflexivo, até porque o objetivo principal do catálogo - ser mecanismo de busca e recuperação de informação - seria abandonado, mas sim mostrar que a interação deles com o comportamental contribui para a satisfação do usuário.

O estudo científico das emoções tem se preocupado bastante com as emoções positivas, tão importantes para o sucesso dos produtos. São elas cada vez mais necessárias na sociedade corrente em que o estresse predomina as casas e trabalho dos indivíduos. Barbara Fredrickson e Thomas Joiner (2002), citados por Norman (2008, p. 128) descrevem as emoções positivas:

As emoções positivas ampliam os repertórios de pensamento-ação das pessoas, encorajando-as a descobrir novas linhas de raciocínio ou ação. A alegria, por exemplo, cria o impulso de brincar, o interesse cria o impulso de explorar, e assim por diante. Brincar, por exemplo, constrói habilidades físicas, socioemocionais e intelectuais, e incrementa o desenvolvimento do cérebro. De maneira semelhante, a exploração aumenta o conhecimento $\mathrm{e}$ a complexidade psicológica (FREDRICKSON; JOINER, 2002 apud NORMAN, 2008, p. 128).

Ora, se há tantos indivíduos estressados, mal humorados, irritados, porque não desenvolver produtos, objetos ou instrumentos de busca e recuperação da informação, que sejam mais atraentes, divertidos e menos maçantes ou sem graça.

Um exemplo de sucesso é o Google, com funcionalidade bem parecida com a de um OPAC, que é considerado divertido, brincalhão, descontraído e positivo por seus usuários. E 
por coisas simples, como esticar o "O" de seu nome conforme o número de páginas de resultados de pesquisa com o tema requerido. Como no exemplo: Goooooooooogle; para dez páginas de resultados obtidos (Exemplo retirado de NORMAN, 2008, p. 128).

São pequenas mudanças, mas que atraem e interagem bem com os usuários do site, e atrairiam e interagiriam bem com os usuários de um catálogo em linha. A noção de diversão retira o lado monótono, sério, formal, de um OPAC, tornando-o um instrumento de recuperação da informação e também um local de descontração, entretenimento. A música seria outro fator positivo, caso fosse agradável, harmoniosa, suave, ao entrar no catálogo ou clicar em uma funcionalidade. Agradando ao nível reflexivo, comportamental, visceral do cérebro e enriquecendo a experiência.

Jordan (2000), também disserta sobre a questão do prazer e do design, especificando quatro tipos de prazer: prazer físico, social, psíquico e ideológico, os quais segundo Norman (2008) se encaixariam dentro dos níveis visceral, comportamental e reflexivo do pensamento.

O prazer físico é aquele ligado ao corpo, sentidos. O prazer social, ligado a interação com as pessoas, a sociedade, devido o uso do produto. O prazer psíquico, ligado ao âmbito psicológico das pessoas ao utilizar produtos. E o prazer ideológico ligado aos valores das pessoas por terem certo produto.

O design emocional aplicado à informação nos OPACs vem da tendência das pessoas de dar e perceber emoções em si mesmas e até em objetos. "Isso é chamado de antropomorfismo, ou seja, a atribuição de motivações, crenças e sentimentos humanos a animais e a objetos inanimados" (NORMAN, 2008, p. 162).

Um exemplo prático disso é quando se culpa o catálogo em linha por não recuperar a informação desejada (afeto negativo) ou o elogia por recuperá-la (afeto positivo). Na verdade a culpa ou elogio deveriam ter sido dados a pessoas, as quais foram responsáveis por tais sucessos ou insucessos. Atribui-se ao produto a responsabilidade pelo prazer ou a culpa pela frustração em relação a uma atividade desejada.

Quanto mais um catálogo interage com o pesquisador, por meio das funcionalidades de sua interface, sua linguagem, sua resposta diante do termo desejado, sua pesquisa avançada, mais se tem a tendência de tratá-lo como um agente ou como ser vivo.

Podemos, portanto acreditar que o objeto de nossa interpretação esteja triste, alegre, zangado ou calmo, dissimulado ou constrangido. E, por sua vez, nós próprios podemos nos tornar emotivos, apenas através de nossa interpretação dos outros. Não podemos controlar estas interpretações iniciais, pois vêm automaticamente, embutidas no nível visceral. Podemos controlar as emoções finais através de análise 
reflexiva, mas as impressões iniciais são subconscientes e automáticas (NORMAN, 2008, p. 164).

Fica explicito nesse ponto que as emoções, iniciais pelo menos, surgem da interação com os produtos, com o impacto que se tem com eles. No caso desta pesquisa, com o impacto que se tem com o catálogo em linha, resultado automático do nível visceral.

Quanto maior a interação, a compreensão, o controle dos usuários com o catálogo, mais confiança eles terão nele. Quanto mais positivo for o contato maior a interação e motivação do usuário com a página. "O afeto positivo resulta no relaxamento de alguns grupos musculares [...], e na tendência de se abrir e se aproximar do acontecimento ou coisa positiva. O afeto negativo tem o impacto oposto, provocando recuo, afastamento" (NORMAN, 2008, p. 208).

Percebe-se com isso que o lado emocional do usuário pode alterar a forma como ele lida com os mecanismos de recuperação da informação, com a informação em si e com a interface do catálogo. Goleman (1998) também teoriza sobre essa temática:

A grande interferência que os transtornos emocionais podem ter na vida mental não é nenhuma novidade para os professores. Estudantes que estão ansiosos, aborrecidos ou deprimidos, não aprendem; pessoas dominadas por esses estados não apreendem informações de maneira eficiente, nem lidam bem com elas (GOLEMAN, 1998, p. 71).

A afirmação do autor é percebida constantemente no meio acadêmico e no contexto dos catálogos em linha de bibliotecas universitárias. Os estudantes nos estados emocionais relatados realmente têm mais dificuldades em apreender informações e lidar bem com elas do que estudantes em estados afetivos positivos, relaxados e felizes.

O design visceral dos OPACs pode atuar exatamente aqui, dando aos usuários essa sensação positiva diante do impacto com sua interface, tornando o aprendizado assim, menos maçante, formal, e mais excitante, diferente, atraente.

O design comportamental pode atuar ligado a função e utilidade, usabilidade e compreensão do OPAC. O design reflexivo ligado à questão da confiança, já abordada anteriormente e à questão da diversão e da interatividade do catálogo, como por exemplo, o logotipo do site do "Google" que são pequenos desenhos animados que mudam freqüentemente, de acordo com a data, época do ano (natal, ano novo, páscoa) ou de acordo com outro motivo. Alterando-se de forma brincalhona e divertindo o usuário, causando boas emoções. 
A figura seguinte mostra a interface do Google, com figura animada:

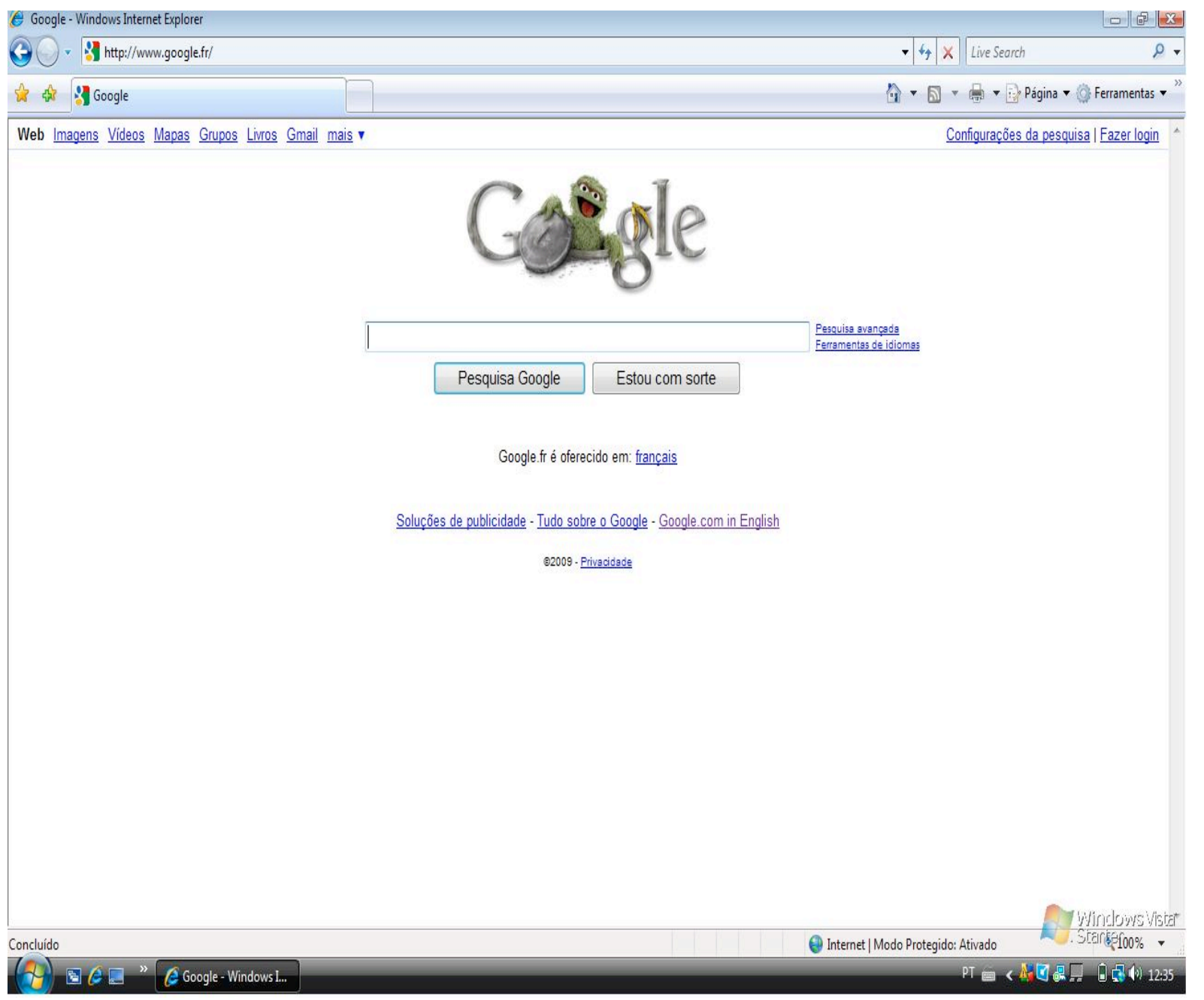

Figura 2 - Interface do site do Google

Fonte: http://www.google.fr

Outra maneira de agradar o usuário seria a personalização da interface, mudanças de cor e tamanho de fonte, como é o caso do site br.msn.com ou do site do hotmail, www.hotmail.com. Também o uso de imagens, figuras pessoais, disposições de ferramentas na tela que seriam fruto do desejo dele, tornando assim a interface do OPAC a "sua" interface, o "seu" mecanismo de busca e recuperação da informação, dando orgulho ao usuário e fazendo com que ele se sinta especial.

A figura seguinte ilustra a interface do MSN, já com a personalização da cor: 


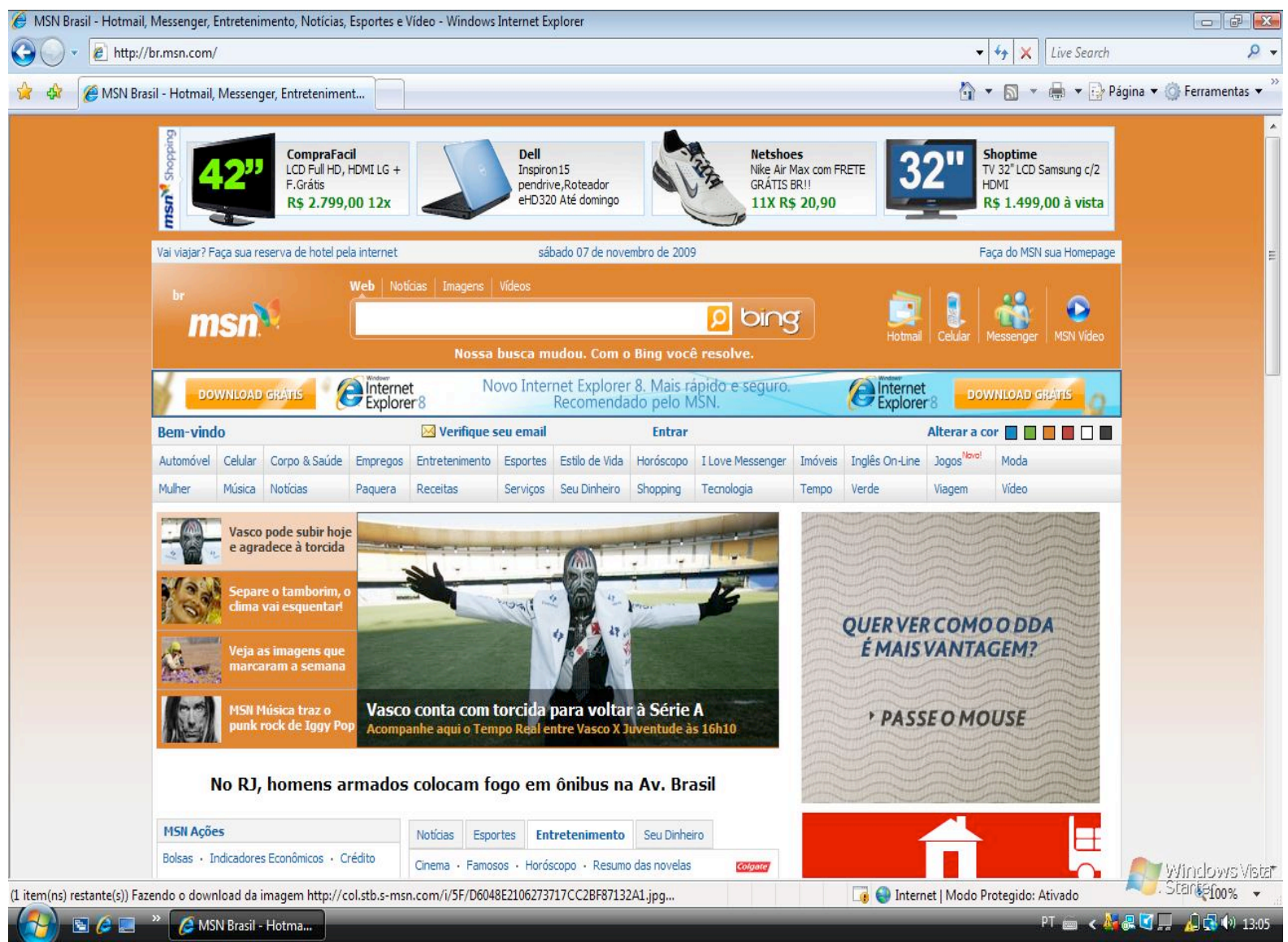

Figura 3 - Interface do site do MSN

Fonte: http://br.msn.com

"Um espaço só pode ser transformado em um lugar por seus ocupantes. A melhor coisa que um designer pode fazer é pôr as ferramentas nas mãos deles" (HARRISON e DOURISH, 1996 apud NORMAN, 2008, p. 254).

Finalizando-se esta parte da revisão de literatura, decidiu-se citar NORMAN (2008):

Quando alguma coisa dá prazer, quando se torna uma parte de nossas vidas, e quando a maneira como interagimos com ela define nosso lugar na sociedade e no mundo, então temos amor. O design faz parte dessa equação, mas a interação pessoal é o segredo. O amor surge por ser conquistado, quando as características especiais de um objeto fazem dele uma parte quotidiana de nossa vida, quando ele intensifica nossa satisfação, quer seja por causa de sua beleza, seu comportamento ou seu componente reflexivo [ou pelo equilíbrio dos três] (NORMAN, 2008, p. 257).

Talvez com os catálogos não se possa ser tão otimista em relação aos seus usuários, mas pelo menos atraentes, confiáveis, prazerosos e divertidos eles poderiam ser. E pensar no design emocional é básico para isso. 


\section{3 - Abordagem metodológica}

A presente pesquisa foi realizada sob o enfoque qualitativo, exploratório, sendo realizado um estudo de caso. Feita como forma de revisão de literatura, por meio de análise de estudos já realizados sobre usabilidade e editoração de páginas de bibliotecas, estudos de usuários, estudos sobre os OPACs, recuperação da informação, editoração e design emocional.

Baptista e Cunha (2007) explicam sobre a pesquisa qualitativa:

\footnotetext{
A pesquisa qualitativa focaliza a sua atenção nas causas das reações dos usuários da informação e na resolução do problema informacional, ela tende a aplicar um enfoque mais holístico do que o método quantitativo. Além disso, ela dá mais atenção aos aspectos subjetivos da experiência e do comportamento humano (BAPTISTA; CUNHA, 2007, p. 173).
}

Pesquisa exploratória porque disserta sobre um tema até então pouco retratado pela literatura científica: o design emocional da informação em catálogos de biblioteca. E visa caracterizá-lo um pouco mais em tal contexto.

Optou-se por um estudo de caso com o público alvo delimitado e com a interface da biblioteca central (BCE) da Universidade de Brasília (UnB). O público alvo do estudo foram 25 usuários do catálogo público de acesso em linha da BCE - UnB. Cabe explicar que a interface desse catálogo é a mesma para todas as bibliotecas integrantes da rede Pergamum, maior rede do Brasil.

Os instrumentos para realização do estudo e da coleta de dados foram bem amplos, incluindo materiais, documentos, livros, artigos de periódicos, teses de doutorado, grupos focais, prototipagem em papel, questionários, entrevistas e observações locais. Em resumo, tudo que pudesse permitir entender como o design emocional pode afetar o usuário na recuperação da informação no catálogo público de acesso em linha, até mesmo a participação em grupos de pesquisa relacionados ao tema, indicados pela orientadora da pesquisa. Como por exemplo, o grupo de pesquisa, informação, design e usabilidade, o qual está situado no sítio:

http://dgp.cnpq.br/buscaoperacional/detalhegrupo.jsp?grupo=0240607FR08HT2 
O trabalho monográfico aborda os assuntos contidos nas seguintes palavras chaves: design emocional, recuperação da informação, catálogo público de acesso em linha.

\subsection{Objetivos}

\section{Objetivo geral}

Identificar qual o impacto que o design (emocional) da interface do catálogo público de acesso em linha tem no usuário e como pode afetá-lo na recuperação da informação.

\section{Objetivos específicos (passos que levam ao objetivo geral)}

1. Caracterizar a recuperação da informação, enfatizando o catálogo público de acesso em linha, como um instrumento de recuperação.

2. Analisar o design da interface do catálogo de acordo com os princípios do design emocional.

3. Descobrir o nível de satisfação dos usuários quanto ao design da interface do OPAC.

4. Apresentar sugestões baseadas no lado emocional dos usuários para enriquecer a diagramação, estrutura e o design da interface.

\subsection{Coleta de dados}

A participação dos usuários do catálogo foi fundamental para o trabalho, porque serviram como fonte de informação, observação e geração de idéias para as alterações realizadas na interface e nos questionários durante a duração da pesquisa.

Foi selecionada como objeto de pesquisa a interface principal do OPAC da BCE da UnB. Ela então foi avaliada, com o intuito de saber se satisfaz ou não o usuário e como o afeta 
emocionalmente. Para então, por meio das respostas obtidas e da análise dos dados, foi criado um modelo ou protótipo idealizado de interface, que tentasse afetar positivamente o usuário e fosse diferente do original. Esse segundo modelo ou protótipo também foi avaliado. Permitindo-se assim o estabelecimento de comparações entre as duas interfaces.

A seleção de apenas uma interface do catálogo - a primeira e principal (homepage) foi definida por ser o primeiro contato do usuário com a página do instrumento de recuperação da informação e por se querer captar as emoções e estados afetivos desse primeiro contato. Já que o foco definido relaciona-se ao design visceral, o das primeiras reações a um produto, o das aparências. Além disso, por questões de aprofundamento na análise da interface.

A interface final sugerida foi resultado de diversas interações com o usuário, do feedback ou retorno deles e de pré-testes, de grupos focais realizados e da aplicação de questionários e de entrevistas relativas ao lado emocional do design.

Visto que sistemas informatizados e a internet já são realidade na maioria das bibliotecas universitárias foi escolhido o catálogo público de acesso em linha e seus respectivos usuários e procurou-se responder a problemática de tornar mais interativa, divertida e emocionalmente positiva a página principal do OPAC da biblioteca.

Considerou-se na coleta de dados as coletas realizadas em dois pré-testes (com 15 usuários) e no teste (final), de 10 usuários, totalizando 25 usuários. Os mesmos foram observados, entrevistados e questionados desde setembro de 2009 até outubro do mesmo ano.

Apesar de o instrumento de coleta de dados (questionário) ter sido melhorado e alterado a cada aplicação, percebeu-se algumas repetições das idéias contidas nas respostas, sem apreensão de idéias novas. Isso se deve em boa parte ao grupo pesquisado ser basicamente de alunos de graduação ou pós, usuários do OPAC. Constituindo-se dessa forma por um grupo semelhante, ligado a pesquisa.

Os usuários participaram da pesquisa em diferentes locais, dias, horários e contextos. Devido ao acesso do OPAC não estar restrito ao espaço físico da biblioteca, nem a determinada hora, dia ou situação. No entanto, todos eram alunos da UnB e usuários da BCE. As fases da pesquisa serão explicadas a seguir:

Primeiro pré-teste: realizado no dia 29/09/2009, com cinco pessoas em forma de grupo focal, com alunos da disciplina Seminário em Arquivística 2: Design emocional, do Departamento de Ciência da Informação e Documentação da UnB. Aos entrevistados foi mostrada a interface original do $\mathrm{OPAC}$ da $\mathrm{BCE}$ e, em seguida, responderam um questionário 
a respeito do impacto emocional da interface, expondo suas impressões, sugestões e contribuições. Logo após, foi mostrada a versão inicial do protótipo em papel da interface modificada e os mesmos pesquisados responderam outro questionário a respeito do impacto emocional da respectiva interface, dando sugestões tanto para a melhoria da interface, como sugestões para a melhoria das perguntas dos questionários.

Segundo pré-teste: realizado no dia 05/10/2009, com 10 pessoas em forma de grupo focal, com os alunos da disciplina Usabilidade na Interação Humano computador, do Departamento de Ciência da Informação e Documentação (CID), da UnB. Aos entrevistados foi mostrada a interface original do OPAC da BCE e em seguida eles responderam um questionário a respeito do primeiro impacto com a interface e expuseram suas impressões, sugestões e contribuições para a melhoria da mesma. Em seguida foi exposta a versão inicial do protótipo em papel da interface modificada e a mesma também foi avaliada. Melhorias para os questionários também foram sugeridas pelo grupo.

Coleta de dados - Teste (final): realizado entre os dias 12/10/2009 e 18/10/2009, com 10 usuários que utilizaram o OPAC da BCE, em distintos terminais de consulta (dentro ou fora da $\mathrm{BCE}$ ) e depois foram entrevistados e levados a responder um questionário melhorado relativo à versão final do protótipo em papel da interface modificada. Nessa fase, tanto o questionário como o modelo do protótipo em papel da interface sugerido para o OPAC já haviam sido melhorados por meio das sugestões, idéias e críticas obtidas nos pré-testes e grupos focais.

\subsection{Instrumento de coleta de dados}

Os instrumentos de coleta de dados utilizados no presente trabalho foram a entrevista, o questionário (apêndices C e D), a observação, o grupo focal, e a prototipagem em papel da interface modificada (anexo A, apêndices A e B).

Cabe ressaltar que os questionários, apesar de serem mais utilizados em pesquisas quantitativas foram utilizados no trabalho com perguntas abertas, em sua maioria. E são essas questões abertas que permitem a coleta de dados qualitativos (BAPTISTA; CUNHA, 2007). As perguntas realizadas neles relacionam-se com os objetivos deste trabalho, pois permitem 
descobrir o nível de satisfação do público alvo quanto ao design emocional da interface do OPAC e quanto ao design emocional dos protótipos em papel das interfaces modificadas. Além disso, as respostas a tais perguntas revelam sugestões e idéias dos próprios usuários para melhorar e enriquecer a interação com as interfaces e a aparência delas. Em suma, contribuem para a consecução do objetivo geral desta pesquisa, o qual foi apresentado no tópico 3.1 .

A observação, a entrevista e o grupo focal, constantemente utilizados nas intervenções com os usuários, permitiram o aprimoramento gradual dos questionários e da prototipagem das interfaces aplicados. De modo que as perguntas se tornaram mais claras, diretas e concisas. E o questionário, como um todo, melhor estruturado. Além disso, por meio das sugestões dos entrevistados foi se alterando a versão original da interface do catálogo e se aprimorando a versão modificada da mesma.

Houve alterações nos questionários ${ }^{1}$ - tanto o aplicado para a interface original como o aplicado para as interfaces modificadas (apêndices C e D). Elas foram realizadas devido:

a) Aos conselhos dados pelos grupos focais que consideraram algumas perguntas dos questionários confusas ou demasiado extensas.

b) A necessidade de agrupar perguntas por partes de forma a ir levando o entrevistado pouco a pouco por meio de suas emoções e primeiras impressões das interfaces.

c) Ao fato de algumas perguntas subjetivas, ficarem melhor se formuladas primeiro de forma objetiva e depois de forma subjetiva.

d) A necessidade de se distribuir mais as perguntas.

e) A falta de identificação do pesquisador nos questionários.

Houve alterações na interface original. Elas foram realizadas devido:

a) A falta de imagens divertidas.

b) A falta de cor e interatividade.

c) A grande quantidade de espaço em branco.

\footnotetext{
${ }^{1}$ Os questionários finais e as imagens das interfaces estão em anexo e apêndice ao final do trabalho.
} 
Houve alterações no primeiro protótipo da interface modificada. Elas foram feitas devido:

a) Cor escura da interface, que causou emoções negativas nos usuários.

b) A algumas figuras da nova interface que não agradaram muito, seja pelo tamanho, pela forma ou pela localização.

\subsection{Limitações da pesquisa}

As principais limitações desta pesquisa foram:

- O estudo de caso com um OPAC específico e apenas com sua interface principal, por se focar no primeiro contato do usuário com o catálogo, sua reação visceral à interface;

- O estudo de usuários realizado com número pequeno de pessoas, para aprofundar melhor na pesquisa, coleta e análise dos dados e por repetições de respostas e idéias obtidas pelos instrumentos de coleta;

- O pequeno espaço de tempo de aproximadamente quatro meses para início e conclusão da pesquisa integralmente;

- O envolvimento de várias áreas, como psicologia, design, biblioteconomia, ciência da computação no tema, o que seria mais bem aproveitado com pesquisadores de diversas áreas.

Estas limitações podem restringir a pesquisa, simplificá-la, mas não implicam em perda de qualidade ou tratamento do tema. Bem como não reduzem sua importância para o contexto da biblioteconomia. 


\section{4 - Análise dos dados}

Para a análise dos dados foi considerada a interface original do OPAC da BCE (anexo A), o protótipo em papel que representa a interface original modificada em sua versão inicial (apêndice A) e o protótipo em papel que representa a interface original modificada em sua versão final (apêndice B). A interface e os protótipos são analisados separadamente.

Cabe explicar que os protótipos em papel modificados foram modelos, sugestões, propostos a partir da interface original do catálogo, com o intuito de torná-lo mais atraente, divertido, interativo e emocionalmente positivo, com base principalmente em sua aparência ou design visceral (NORMAN, 2008) que são o foco da pesquisa.

De acordo com os objetivos específicos do trabalho a idéia é analisar o design da interface do catálogo de acordo com os princípios do design emocional, descobrir o nível de satisfação dos usuários quanto ao design da interface, para então poder apresentar sugestões que possam enriquecer o design da interface do OPAC.

Seguem-se nos tópicos as análises dos dados obtidos pelos instrumentos de coleta de dados.

\subsection{Interface original ${ }^{2}$}

A primeira pergunta feita foi como o estado afetivo dos usuários ficava diante da interface e porque ficava de determinado jeito. Pelas observações feitas e pelos dados colhidos nos questionários dos testes e pré-testes, verificou- se que a maior parte, 20 usuários, ficava com o estado afetivo neutro, mostrando indiferença pela aparência do catálogo.

No momento de especificarem as causas de tal estado afetivo, alguns relataram que a interface era simples, enxuta. Outros que ela não provocava nenhuma emoção e não trazia nada de atrativo.

Estilos simples ainda predominam em muitas interfaces de catálogos e esses estilos normalmente causam nas pessoas esse estado afetivo neutro, de indiferença, constatado. Mas, seria interessante que o contato com o OPAC, em relação à aparência deste instrumento de recuperação de informação, causasse um estado afetivo positivo nos usuários, visto que

\footnotetext{
${ }^{2} \mathrm{O}$ instrumento de coleta aplicado à interface original do OPAC pode ser consultado no apêndice $\mathrm{C}$.
} 
tornaria os usuários mais satisfeitos. "Objetos atraentes, de fato, funcionam melhor atratividade produz emoções positivas, fazendo com que os processos mentais sejam mais criativos, mais tolerantes diante de pequenas dificuldades" (NORMAN, 2008, p.82).

A segunda pergunta apresentada foi como se sentiam ao ver a interface, pergunta aplicada a fim de complementar a primeira. As respostas, como já esperado, foram muito variadas. Afinal, não existem regras no âmbito emocional. 10 usuários sentiram-se irritados porque não encontraram o que queriam ou demoraram a encontrar. Outros 8 se sentiram indiferentes, tranqüilos, porque já haviam se acostumado com o catálogo. E ainda tiveram sete usuários que se sentiram curiosos em utilizar a interface ou intrigados, pois não sabiam a melhor maneira de encontrar o que queriam. Observou-se também que muitas pessoas não entenderam o porquê de ser importante saber a forma como se sentiam diante de um instrumento de pesquisa.

O que se pode comentar aqui e foi mostrado pelas respostas é que a aparência do OPAC importa. Ela afeta o usuário. Fazendo-o se sentir bem, mal, ou de outra forma. No entanto, o usuário pensa que a estética não faz diferença porque o nível visceral de seu pensamento, o das aparências, é subconsciente. Por isso, não o valoriza (NORMAN, 2008).

Além disso, a importância da forma como se sentem os usuários diante do OPAC já foi comprovada na parte teórica, visto que afeta a qualidade da pesquisa deles.

A terceira pergunta feita aos participantes da pesquisa foi o que mudariam na interface do catálogo e por que. A maior parte das respostas, mais precisamente 18, se concentrou na mudança de cores, as quais foram consideradas pouco atraentes, sem graça ou muito simples, sem variações. Os sete pesquisados restantes não tinham opiniões quanto a esse aspecto ou mudariam pequenos detalhes na tela, como a disposição de ícones ou de menus.

Isso se deve pela pequena quantidade e variação de cores na tela do OPAC, que é predominantemente azul e branca, com pequenos contrastes na tonalidade do azul. Observouse igualmente que os usuários consideraram a tela vazia, com grandes espaços não preenchidos, o que os incomodou um pouco.

Norman (2008) evidenciou em suas pesquisas a relevância das cores para o nível visceral da estrutura cerebral ao relatar que o nível visceral é pré-programado a responder positivamente a cores intensamente saturadas, a cores intensas, primárias. Também mostrou que esse nível responde negativamente a terrenos vazios. Adaptando ao catálogo, grandes espaços vazios na tela incomodam os usuários. 
Assim, uma interface com um leque mais variado de cores agradaria mais o primeiro contato das pessoas com o OPAC e uma tela mais preenchida, sem grandes vazios, seria mais bem recebida por elas.

A quarta questão colocada foi se os usuários achariam interessante a personalização da interface do catálogo, com a escolha da cor, fonte, tamanho ou a criação de um perfil próprio.

Quase que a totalidade, 22 usuários, respondeu que sim, que gostariam de personalizar o OPAC. Essa personalização não é novidade, visto que um grande número de páginas na internet oferece esse recurso aos seus usuários e é um recurso valorizado pelos mesmos. Provavelmente, porque torna o site mais atraente aos olhos da pessoa que o utiliza e permite que ela defina como quer vê-lo.

O gosto pela personalização de produtos é um fato notório na sociedade globalizada que se vive atualmente, aonde a produção de massa torna os produtos todos iguais, padronizados.

As próprias interfaces dos catálogos de biblioteca, como as dos OPACs das bibliotecas da rede Pergamum, são todas padronizadas, quase sem variações. E a personalização, a criação de um perfil, permitiria que os usuários tivessem algo "seu", algo diferenciado e conforme seus próprios desejos. Uma página com suas características, fotos, livros de interesse, entre outros.

A quinta questão aplicada foi se os usuários consideram que suas emoções diante da interface podem ser mais decisivas para o sucesso dela do que seus elementos práticos e por que. 17 usuários consideraram que sim, suas emoções são importantes para o sucesso do OPAC. Isso demonstra a importância e o impacto do design emocional da informação na página dos catálogos de bibliotecas.

Os motivos apresentados foram: elementos empolgantes podem incentivar o uso da interface por mais complicado que seja; se a interface proporcionar ao usuário sentimentos de esperteza, empolgação, ele vai achá-la mais prática; caso a interface seja mais agradável, a motivação será maior para utilizar a página ou voltar a utilizá-la, entre outros. Oito usuários disseram que não, que a parte técnica, operacional, dos OPACs era mais relevante que as emoções.

Ficou claro na análise dessa questão, que o sistema emocional pode influenciar o sistema cognitivo. O afeto positivo pode auxiliar na tomada de decisões, pois pessoas que estão mais relaxadas e felizes expandem sua imaginação, sua criatividade, buscam mais alternativas para realizar sua tarefa. Devido a isso, emoções boas causadas pela aparência 
positiva da interface podem fazer com que seus elementos reais se tornem menos complicados, difíceis, para os usuários (ISEN, 1993).

Norman (2008) ainda relata que de forma geral, as pessoas são primeiramente emocionais na tomada de decisões para depois avaliá-las cognitivamente. A explicação dessa ordem é que o lado emocional permite maior rapidez na tomada de decisões, por ser subconsciente. Somente depois, que as pessoas avaliam realmente as decisões que tomaram, de forma consciente e racional.

A sexta pergunta feita foi se eles gostariam que a interface fosse mais divertida e brincalhona, como a interface do Google o que pudessem deixar suas sugestões para a melhoria da mesma.

Quase a totalidade, 20 das respostas coletadas, foi sim. O que revela a importância do lado divertido, brincalhão, de uma interface, mesmo de um catálogo público de biblioteca, porque esse lado mexe com a emoção dos usuários e os deixa mais felizes, dispostos e abertos para suas pesquisas. A interface do Google foi usada como exemplo, porque estudos científicos elogiaram-na e relataram a idéia de diversão que as pessoas sentem ao entrar em contato com a página, que sempre "brinca" com elas (NORMAN, 2008).

A sétima questão aplicada e a nona serão mostradas juntas, pois seu tema envolve primordialmente o design comportamental, o qual não é foco da presente monografia. Portanto, serão mostrados apenas os dados colhidos, eles não serão analisados.

Respectivamente, as perguntas foram: o produto satisfaz suas necessidades de busca e recuperação de informação, se não, por quê; e o catálogo público de acesso em linha tem um bom desempenho, usabilidade.

Em geral, as respostas obtidas foram positivas (sim). Apenas sete usuários disseram não e destacaram que nem sempre o OPAC é eficiente nas buscas e recuperações.

A oitava questão perguntada foi se considera que a interface do catálogo foi construída levando em consideração o modelo mental do usuário na busca por informação ou o modelo de um especialista e por que. Neste ponto houve divisão de opiniões. 14 usuários acharam que a interface seguiu o modelo de um especialista porque os usuários, em geral, não estão habituados com aquela disposição de opções de pesquisa. 11 acharam que seguiu o modelo do usuário, porque os elementos da página são simples e fáceis de utilizar.

Norman (2008) expõe que:

"Para alguém usar um produto com sucesso, precisa ter o mesmo modelo mental (o modelo do usuário) do designer (o modelo do designer)" (NORMAN, 2008, p. 99). Logo, 
interpretando essa afirmação, cabe aos designers ou projetistas de interfaces encontrarem maneiras de adaptar seus produtos ou interfaces aos usuários.

Aplicando-se ao OPAC, é fundamental que leve em conta os usuários na hora de se projetar tal instrumento de recuperação de informação, visto que são eles próprios a razão de existir do catálogo, assim como das bibliotecas. A aparência do OPAC então deve facilitar a pesquisa e o encontro das informações utilizadas, com enlaces ou Hiperlinks, contendo as partes que os usuários mais utilizam no catálogo, para se sentirem melhor localizados na interface.

Observou-se nas atitudes dos pesquisados que as emoções são essenciais para eles gostarem ou não da recuperação da informação no OPAC e mexem sim com suas opiniões e sensações diante dele. Além disso, muitas foram as sugestões para tornar a página de abertura do OPAC mais atraente, divertida, interativa.

Foi nesse sentido que foram representadas as modificações da interface num protótipo em papel, para serem analisadas as reações dos usuários. Os dados coletados serão analisados nos tópicos adiante.

\subsection{Versão inicial do protótipo em papel da interface modificada}

Nesta versão da interface as cores foram completamente alteradas e o grande espaço vazio que havia na tela foi preenchido por figuras, as quais seriam hiperlinks que fazem as ações descritas neles e representariam as ações mais realizadas pelos usuários no catálogo. Por exemplo: ajuda, acesso ao usuário, renovação de livros, pesquisa, entre outros.

As imagens poderiam até se mexer e fazer ações correspondentes ao que representam. Exemplos: a estrela poderia brilhar; a nuvem chover. Elas seriam personalizadas de acordo com a época do ano, como no natal, com figuras natalinas, ou na páscoa, com coelhinhos e ovos de páscoa, ou seriam escolhidas pelos usuários (apêndice A).

Elas também estariam associadas a significados. Exemplificando: a estrela com o link de acesso ao usuário significaria que o usuário é a estrela, o foco, do OPAC; o coração com o link para a pesquisa significaria que o usuário ama a pesquisa; a nuvem com o link para a ajuda significaria que “o tempo está nublado para o usuário, pode até chover”, pois ele está com dúvidas. 
Por meio dos pré-testes foram coletados dados de 15 usuários para a análise do design desta versão inicial da interface modificada, os quais são analisados a partir daqui.

A primeira questão levantada foi como se sentiam os usuários diante da nova interface. Observou-se que a interface mexeu com as emoções dos usuários. Dez deles ficaram confusos e assustados, disseram não saber se iriam se acostumar com as mudanças. Outra parte, cinco dos usuários, achou a nova interface positiva, divertida e sentiu-se sensibilizada pela drástica mudança no design visceral.

Em seguida, na mesma questão foi perguntado como ficou o estado afetivo dos usuários e por que. Conforme as respostas anteriores, cinco colocaram seu estado afetivo como positivo porque consideraram a interface mais alegre, bem diferente do design tradicional de outros OPACs, e dez colocaram seu estado afetivo como negativo porque as cores escuras causavam sensações ruins ou dificultavam a leitura das informações.

A rejeição mostrada talvez possa ser justificada pelas condições pré-programadas do nível visceral de pensamento que considera como negativo cores muito escuras, sombrias, extremamente fortes, objetos pontiagudos (NORMAN, 2008). E a aceitação verificada talvez possa ser justificada com base no uso das imagens, que tornou o OPAC menos formal, frio e comum. Além do que o uso de cores de tonalidades intensas e bem coloridas nas figuras fez os usuários as adorarem e ficarem com bons sentimentos. É necessário esclarecer que não há uma receita ou fórmula exata para a aceitação de uma interface pelos seus usuários.

A segunda questão colocada foi o que considerariam como negativo em uma interface e exemplos de coisas negativas. As respostas foram em geral: excesso de imagens ou informações (3); informações mal distribuídas e apresentadas (3); fundos muito escuros (3); cores muito fortes, sombrias (2); falta de opção quanto à escolha de cores da página (3); letras ou ícones muito pequenos (1).

As respostas demonstram que as pessoas tendem naturalmente a rejeitar cores muito escuras, excesso de informações nas interfaces, informações estruturadas de forma não harmoniosa ou não simétrica, e fundos ditos sombrios ou pesados. Essa rejeição se dá automaticamente, em seu nível mais superficial de pensamento (NORMAN, 2008). Já as letras ou ícones muito pequenos sofrem rejeição pela dificuldade de visualização e leitura.

A terceira questão exposta aos usuários foi o que os atrairia a utilizar uma interface, levando em conta a aparência da tela e exemplos de coisas positivas. As respostas obtidas foram: cores agradáveis, telas harmoniosas, suaves (5); o uso de imagens ilustrativas (3); poder personalizar a interface e interagir com ela (7); 
Isso demonstra a tendência natural das pessoas de aceitar positivamente objetos e formas que sejam harmoniosas, simétricas, suaves, pois agradam visceralmente seu cérebro. E também de como interfaces mais interativas e divertidas, personalizadas, são consideradas mais positivas, porque mexem emocionalmente, de forma positiva, com os usuários. Informações bem organizadas e editoradas também.

Para verificar a idéia que os usuários têm de interatividade e diversão em uma interface perguntou-se na quarta questão o que eles fariam para ela ser mais interativa e divertida. Alguns não souberam opinar ou relataram que não fariam nada (2). Outros disseram que: colocariam mais cores (2); permitiriam que o usuário personalizasse a interface, mudando cores, ícones, tamanhos (4); dividiriam o conteúdo por categorias (1); usariam figuras atrativas (2); disponibilizariam links (4).

Observou-se que a idéia proposta, de colocar as funções mais utilizadas do catálogo em destaque, por meio do uso de imagens com links, foi bem recebida.

Constata-se que o usuário quer uma interface mais interativa e divertida, porém nem sempre sabe como gostaria que ela fosse. Cabem a este trabalho apenas sugestões, estas são os hiperlinks, que descontrairiam o lado formal do catálogo, e formas divertidas, harmoniosas e coloridas que agradem a visualização e façam o usuário lembrar-se de coisas boas, baseadas no design visceral e reflexivo (NORMAN, 2008).

$\mathrm{Na}$ quinta questão foram pedidos exemplos de interfaces que os usuários amam ou odeiam e o porquê de amar ou odiar. Essa questão foi feita com o intuito de saber o que é considerado emocionalmente positivo e negativo nas interfaces, e utilizar as idéias para inspirar a versão final do protótipo em papel da interface modificada.

Em geral, interfaces possíveis de personalização, com maior interação com os usuários foram amadas. E interfaces com excesso de informação e poluição visual foram detestadas.

Aqui se verifica a relevância do princípio de legibilidade de Araújo (1986 apud HOELTZ, 2001), o qual explicita que a correta disposição das palavras contribui para tornar a página mais agradável. Complementando, não somente a correta disposição das palavras, mas também a correta utilização das cores, das imagens, da quantidade de informações e da possibilidade de escolha contribui para esse ideal.

A sexta, a sétima e a oitava questões foram elaboradas com o intuito de diversão e interatividade para o catálogo, complementando algumas das questões anteriores. As respostas obtidas serão analisadas juntas por terem sido, em sua maioria, as mesmas.

$\mathrm{Na}$ sexta questão foi perguntado se o usuário gostaria que o sítio do OPAC se adaptasse às datas correntes com imagens, por exemplo, diabinhos na tela no dia das bruxas, 
ou gorros de neve no inverno, como o site do Google. Nos pré-testes foi sugerido retirar o exemplo do Google, por ter sido considerado tendencioso. Tal modificação foi realizada para a coleta de dados da versão final da interface modificada.

$\mathrm{Na}$ sétima questão foi perguntado se o usuário gostaria de participar da escolha de futuras imagens do OPAC, dando sugestões. E na oitava questão, se ele gostaria que essas imagens fossem hiperlinks para as partes mais usadas no catálogo, como a ajuda ou o acesso ao usuário.

Parte significativa das respostas obtidas nestas três perguntas (sexta, sétima e oitava) foi sim (de 14 usuários apenas um disse que não). Observou-se grande aprovação das pessoas em relação às idéias propostas para a página. Confirmando assim, que imagens realmente podem tornar a aparência de um OPAC mais atraente, mais divertida e positiva. Podendo trazer alegria para a vida do usuário, tornando a pesquisa algo menos padronizado, mais visceralmente atraente (NORMAN, 2008). E por meio da participação dele no catálogo, aumenta-se a interatividade entre sujeito e objeto, usuário e OPAC.

A intenção da nona questão foi avaliar a interface sugerida, de maneira simples e de acordo com os três tipos de designs propostos por Norman (2008): visceral, comportamental e reflexivo. Foi questionado que adjetivo os usuários atribuiriam aos seguintes aspectos da interface: aparência da tela, usabilidade da imagem no catálogo, qualidade das lembranças ou associações que ele te traz. As respostas estavam limitadas a boa ou ruim, para facilitar a análise.

Em relação à aparência - design visceral - da interface as respostas ficaram muito divididas entre boa (6) e ruim (9). Conclui-se que a interface não agradou visceralmente.

Em relação à usabilidade das imagens - design comportamental - no catálogo, mais da metade das respostas obtidas (9) foi positiva. Conclui-se que a interface agradou no nível comportamental. No entanto, podia ser melhorada.

Em relação à qualidade das lembranças ou associações - design reflexivo - que o catálogo provoca nos usuários a maior parte das respostas (10) foi positiva. Conclui-se que a interface também agradou no nível reflexivo de pensamento, mas que podia ser melhorada.

A avaliação da versão inicial do protótipo em papel da interface modificada foi importante nos pré-testes porque mostrou que a aparência da tela, as imagens e as cores utilizadas não agradaram tanto aos usuários quanto foi previsto. O nível de satisfação dos mesmos foi considerado mediano ou baixo. Então, resolveu-se aprimorar essa versão inicial, chegando-se a uma versão final. Esta foi a versão utilizada na coleta de dados - teste (final), cujo questionário está no apêndice D. 
Tal versão e os dados obtidos pelos instrumentos de coleta de dados para avaliá-la serão analisados no tópico seguinte.

\subsection{Versão final do protótipo em papel da interface modificada ${ }^{3}$}

De imediato já se observou empatia pelo design emocional da informação na versão final do protótipo em papel da interface do catálogo, a qual foi avaliada por 10 usuários. Todos eles se mostraram muito mais receptivos ao novo design, sentindo-se em geral emocionalmente positivos.

Nesta versão, optou-se por manter a cor clara do plano de fundo original do OPAC e estendê-lo para o restante do corpo da página, eliminando o grande espaço vazio que havia na tela, o qual foi motivo de tantas reclamações mostradas nos pré-testes com os usuários. Decidiu-se utilizar imagens de carinhas felizes, sorridentes, para representar os hiperlinks para as partes mais utilizadas do catálogo, pois formas arredondadas tendem naturalmente a agradar os usuários no nível visceral (NORMAN, 2008) e rostos sorridentes podem contribuir para lembrar as pessoas de momentos felizes.

Além disso, foram utilizadas cores de matizes intensamente saturadas, cores primárias, e formas como as retratadas no parágrafo anterior, inspiradas nas cores e formas que as pessoas encontram na natureza e percebe-se, de forma clara, que as agradam. Frutas e flores tendem a ser simétricas, arredondadas, lisas, agradáveis ao toque e coloridas (NORMAN, 2008). Tentou-se tudo isso com as imagens sugeridas nesta versão final (apêndice B).

A idéia de personalização, a mesma da versão inicial da interface, foi mantida devido ao desejo dos 15 usuários, sentidos nos pré-testes. Uma imagem com o hiperlink "personalize” foi disponibilizada. A intenção é que os usuários possam mudar a cor da página, a fonte, o tamanho dos ícones e das letras, e até mesmo possam escolher as figuras que os agradem ou atraiam, tornando o OPAC mais divertido, interativo e principalmente mais visceralmente atraente.

Um questionário aberto - versão melhorada do questionário dos pré-testes - foi aplicado, em forma de teste, com 10 reais usuários da BCE, em locais diversos e contextos variados (no campus da UNB, no trabalho ou na casa dos usuários) para avaliar o design da

\footnotetext{
${ }^{3} \mathrm{O}$ instrumento de coleta aplicado à versão final do protótipo em papel da interface modificada pode ser consultado no apêndice D.
} 
interface, a qual seguiu princípios do design emocional para melhorar seu design gráfico. A análise das respostas obtidas está a seguir.

$\mathrm{Na}$ primeira questão perguntou-se como se sentiam os usuários diante da interface modificada. As respostas foram: motivado (2 usuários); feliz (2); bem confortável e tranqüilo com as cores e com os links que são diretos para os serviços da biblioteca(1); alegre, divertido, cômico (2); mais confortável para realizar a pesquisa, os hiperlinks me ajudariam (2); confuso (1).

Revela-se a aprovação da nova interface pelos usuários do OPAC. As alterações na aparência da tela mexeram positivamente com as emoções deles e até fizeram com que eles estivessem mais receptivos e dispostos para a pesquisa, conforme as idéias de Norman (2008).

"O afeto positivo resulta no relaxamento de alguns grupos musculares [...], e na tendência de se abrir e se aproximar do acontecimento ou coisa positiva" (NORMAN, 2008, p. 208).

Na mesma questão ainda se perguntou como ficava o estado afetivo dos pesquisados, a grande maioria (9 usuários), como já evidenciado pela parte anterior, ficou com estados afetivos positivos, pois estavam relaxados e receptivos para a pesquisa. A aparência do OPAC os agradou visceralmente e os deixou dessa maneira.

As questões de dois a oito, apesar do questionário do teste ter sofrido um pouco de alterações, são iguais àquelas aplicadas nos pré-testes e tiveram muitas repetições nos conteúdos das respostas, sem aparecimento de idéias novas. Portanto, decidiu-se não descrever aqui a análise dos dados obtidos nessas questões, sendo igualmente válida a análise dos dados obtidos na versão inicial do protótipo em papel da interface modificada. Passa-se então para a próxima questão.

$\mathrm{Na}$ nona questão foi perguntado o adjetivo que os usuários atribuiriam aos designs visceral, comportamental e reflexivo da interface. Dever-se-ia escolher entre boa ou ruim.

Quanto ao design visceral ou aparência da tela, ao design comportamental ou usabilidade da imagem no OPAC, ao design reflexivo ou a qualidade das lembranças ou associações que o catálogo provoca nos usuários, todas as respostas obtidas foram positivas. Todos os pesquisados consideraram bons os três tipos de designs da nova interface.

Conclui-se que as idéias dos hiperlinks, da personalização da página, do preenchimento de espaços vazios, as imagens e as cores escolhidas contribuíram definitivamente para o sucesso do novo OPAC. Eles retiraram o lado excessivamente formal e sóbrio do catálogo, dando a impressão de facilidade, leveza, tornando a pesquisa não algo 
sacrificante, chato e monótono, mas sim algo divertido, interativo, colorido. Uma atividade que dá vontade de voltar a fazer e não de desistir.

Observou-se que os princípios do design emocional, cores primárias, formas arredondadas, simétricas, suaves e harmoniosas, espaços preenchidos na medida certa, a possibilidade de alteração de cores e imagens pelo usuário, enfim tudo que foi exposto durante o trabalho e principalmente, o afeto positivo, causado pela interface nos usuários contribuiu para o sucesso da interface do OPAC, trazendo a emoção e o prazer ligado a ela para o contexto bibliotecário, mais especificamente ao contexto dos catálogos públicos de acesso em linha. 


\section{5 - Conclusões}

A biblioteconomia por ser uma ciência que organiza a informação, tem na recuperação da informação uma área de destaque fundamental. Afinal, tudo que é organizado tem a finalidade de ser recuperado posteriormente e ser principalmente utilizado pelos usuários.

São vários os instrumentos para recuperar informações. Considerou-se o catálogo público de acesso em linha como um instrumento especial dentre eles, por sua relação com um dos meios mais utilizados e enfatizados atualmente para as pesquisas: a internet.

O intuito do presente trabalho (objetivo geral), assim como seus objetivos específicos serão relatados e avaliados a seguir, de forma sintetizada.

O primeiro objetivo específico deste trabalho foi caracterizar (e definir) a recuperação da informação, enfatizando o catálogo público de acesso em linha, como um instrumento de recuperação. Esse objetivo foi atingido por meio da revisão de literatura e textos científicos que abordaram tais assuntos, sistematizando esse relevante conhecimento para a área da biblioteconomia, tão preocupada com a recuperação da informação e bastante marcada atualmente, no contexto da rede mundial de computadores, pela presença dos OPACs e de redes de bibliotecas que os utilizam para mostrar ao mundo seus conhecimentos registrados. Com a finalidade de compartilhar conhecimento.

O segundo objetivo específico foi analisar o design da interface do OPAC da BCE $\mathrm{UnB}$, de acordo com princípios do design emocional. Decidiu-se focar no design visceral da interface, mas o design comportamental e o reflexivo também foram considerados. O objetivo foi atingido por meio de estudos sobre o design emocional aplicados ao âmbito da biblioteconomia e da informação. Verificou-se, por meio dos instrumentos de coleta de dados, indiferença emocional em relação a esses três aspectos do design da homepage do catálogo, por ela ser relativamente simples e de estilo comum, igual a vários outros OPACs.

O terceiro objetivo específico foi descobrir o nível de satisfação dos usuários quanto ao design da interface do OPAC. Esse objetivo foi alcançado por meio da aplicação de questionários, grupos focais, observações e entrevistas com 25 reais usuários da biblioteca da Universidade, logo após verem a interface da homepage do catálogo. Tentou-se captar a reação emocional dos usuários diante da tela. Em relação à interface original, 20 usuários ficaram com estados afetivos neutros. Ou seja, a aparência do catálogo não foi considerada muito atrativa ou provocou emoções, pois o seu estilo é predominantemente formal, sóbrio. 
Observou-se que o nível de satisfação com o OPAC era mediano (estado afetivo neutro) e podia ser melhorado caso o design visceral da interface provocasse estado afetivo positivo nos pesquisados e caso o design reflexivo provocasse boas relações com a página. Isto motivou as alterações feitas nas versões inicial e final dos protótipos em papel das interfaces modificadas.

O quarto objetivo específico foi apresentar sugestões baseadas no lado emocional dos usuários para enriquecer a diagramação, estrutura e o design da interface. Focou-se igualmente no design visceral do OPAC, no entanto os outros designs foram considerados. Tais sugestões foram postas nas versões inicial e final dos protótipos em papel das interfaces modificadas. Percebeu-se, que a versão inicial mexeu com as emoções das pessoas, mas ela não foi aprovada quanto o esperado, pois provocou algumas sensações negativas pelo uso de cores escuras, imagens muito grandes e pontiagudas na tela. Nesse ponto (na versão inicial) o objetivo não foi alcançado. Já a versão final foi muito bem aceita no teste por todos os 10 usuários nos três níveis visceral, comportamental e reflexivo, porque seguiu alguns princípios do design emocional. Especialmente, com cores primárias, imagens harmoniosas, arredondadas, rostos sorridentes, preenchimento de espaços vazios na tela, entre outros. Causando estado afetivo positivo e motivando os usuários a utilizar o OPAC. Na versão final, portanto, o objetivo foi alcançado, enriquecendo-se o design da interface.

Os quatros objetivos específicos relatados e avaliados levaram à realização do objetivo maior deste estudo (o objetivo geral) de identificar qual o impacto que o design emocional da informação na interface do catálogo público de acesso em linha tem no usuário e como pode afetá-lo na recuperação da informação. Identificou-se no OPAC que o design emocional da informação influencia claramente os usuários, é um elemento chave no momento em que eles realizam a busca por informações. Esse tipo de design os impacta no sentido em que pode causar neles sensações positivas, de receptividade e abertura para a pesquisa, aproximando-os do catálogo e mexendo positivamente com seu lado emocional ou afastá-los, causando sensações negativas ou neutras, e aversão para a pesquisa, mexendo negativamente com suas emoções, porque não os motiva.

Esse tipo de impacto foi demonstrado por meio da coleta e análise dos dados coletados nas entrevistas e questionários.

Por fim, conclui-se que a emoção realmente influencia os usuários no momento de recuperar informações e que uma aparência divertida, atraente e interativa nos catálogos das bibliotecas torna a recuperação um processo mais interessante, menos difícil e mais motivador, conforme revelado na versão final do protótipo em papel da interface modificada. 
Este é o impacto que o design emocional da informação da interface do OPAC tem no usuário, desta maneira pode afetá-lo na recuperação da informação. 


\section{6 - Referências Bibliográficas}

BAPTISTA, Sofia Galvão; CUNHA, Murilo Bastos. Estudos de usuários: visão global dos métodos de coleta de dados. Perspectivas em ciência da informação, v. 12, n. 2, p. 168-184, maio/ago. 2007.

CINTRA, Anna Maria Marques et al. Para entender as linguagens documentárias. São Paulo: Polis, 1994.

GOLEMAN, D. Inteligência emocional. Rio de Janeiro: Objetiva, 1998.

HOELTZ, Mirela. Design gráfico: dos espelhos às janelas de papel. 2001. Disponível em: $<$ http://www.bocc.ubi.pt>. Acessado em setembro de 2009.

ISEN, A. M. Positive affect and decision making. In: LEWIS, M.; Haviland, J. M. (Eds.), Handbook of emotions. Nova York: Guilford, 1993. p. 261-277.

ISO 9241-11. Ergonomic requirements for Office work with visual display terminals (VDTs). International Standard ISO 9241. Parte 11: guidance on usability. 1994. Disponível em: $<$ http://www.usability.ru/sources/iso9241-11.htm>. Acessado em outubro de 2009.

JORDAN, P. W. Designing pleasurable products: an introduction to the new human factors. Londres: Taylor \& Francis, 2000.

KAFURE, Ivette. Usabilidade da imagem na recuperação da informação no catálogo público de acesso em linha. Orientador: Cunha, Murilo Bastos da. Brasília: UNB, 2004. xv, 311 f. p. Tese(Doutorado Ciência da Informação)-Universidade de Brasília. Departamento de Ciência da Informação e Documentação. Inclui bibliografia e anexos.

MEY, Eliane S. A. Catalogação no plural. Brasília: Briquet de Lemos, 2009. 
MEY, Eliane S. A. Introdução a catalogação. Brasília: Briquet de Lemos, 1995.

NORMAN, Donald A. Design emocional: por que adoramos (ou detestamos) objetos do diaa-dia. Rio de Janeiro: Rocco, 2008.

PIGNATARI, D. Informação. Linguagem. Comunicação. São Paulo: Perspectiva, 1977.

ROWLEY, Jennifer. A biblioteca eletrônica. Tradução de Antonio Agenor Briquet de Lemos. 2. ed. de Informática para Bibliotecas. Brasília: Briquet de Lemos, 2002.

SARACEVIC, T. Ciência da informação: origem, evolução e relações. Perspectivas em ciência da informação, Brasília, v.1, n.1, pp. 4-62, jan./jun. 1996. 


\section{Glossário}

Decidiu-se definir ou complementar alguns conceitos utilizados a fim de dar melhor compreensão ao corpo do trabalho.

Afeto: termo genérico que se aplica ao sistema ao sistema de julgamentos quer sejam conscientes ou inconscientes (NORMAN, 2008, p. 31).

Catálogo: instrumento de recuperação da informação. Pode ser impresso ou virtual.

Catálogo Público de Acesso em Linha: instrumento virtual de recuperação da informação. Ele é de acesso livre e pode ser acessado de qualquer local com internet.

Emoção: é a experiência consciente do afeto, completa com a atribuição de sua causa e identificação de seu objeto (NORMAN, 2008, p. 31).

Homepage: pode ser entendido no português como página de abertura. É a primeira página que o usuário visualiza ao entrar em um site na internet. É conhecida também como página casa ou página principal (base) de um site.

Interface original: interface inicial do OPAC da BCE.

Nível comportamental: diz respeito ao uso, é sobre a experiência com um produto. Função, desempenho, usabilidade (NORMAN, 2008, p. 56).

Nível reflexivo: é onde a consciência e os mais altos níveis de sentimento, emoções e cognição residem. Interpretação, compreensão e raciocínio só ocorrem nele (NORMAN, 2008, p. 57).

Nível visceral: é pré-consciente, anterior ao pensamento. É onde a aparência importa e se formam as primeiras impressões (NORMAN, 2008, p. 56).

Protótipo em papel da interface modificada: versões, modelos feitos para a interface do OPAC da BCE.

Sistema afetivo: faz julgamentos e rapidamente ajuda você a determinar as coisas no ambiente que são perigosas ou seguras, boas ou más (NORMAN, 2008, p. 31).

Sistema cognitivo: interpreta ou explica o sentido lógico do mundo (NORMAN, 2008, p. $31)$.

Usabilidade: descreve a facilidade com que o usuário do produto pode compreender como ele funciona e como fazê-lo funcionar (NORMAN, 2008, p. 57). 


\section{Apêndice}

APÊNDICE A - Versão inicial do protótipo em papel da interface modificada do OPAC da BCE

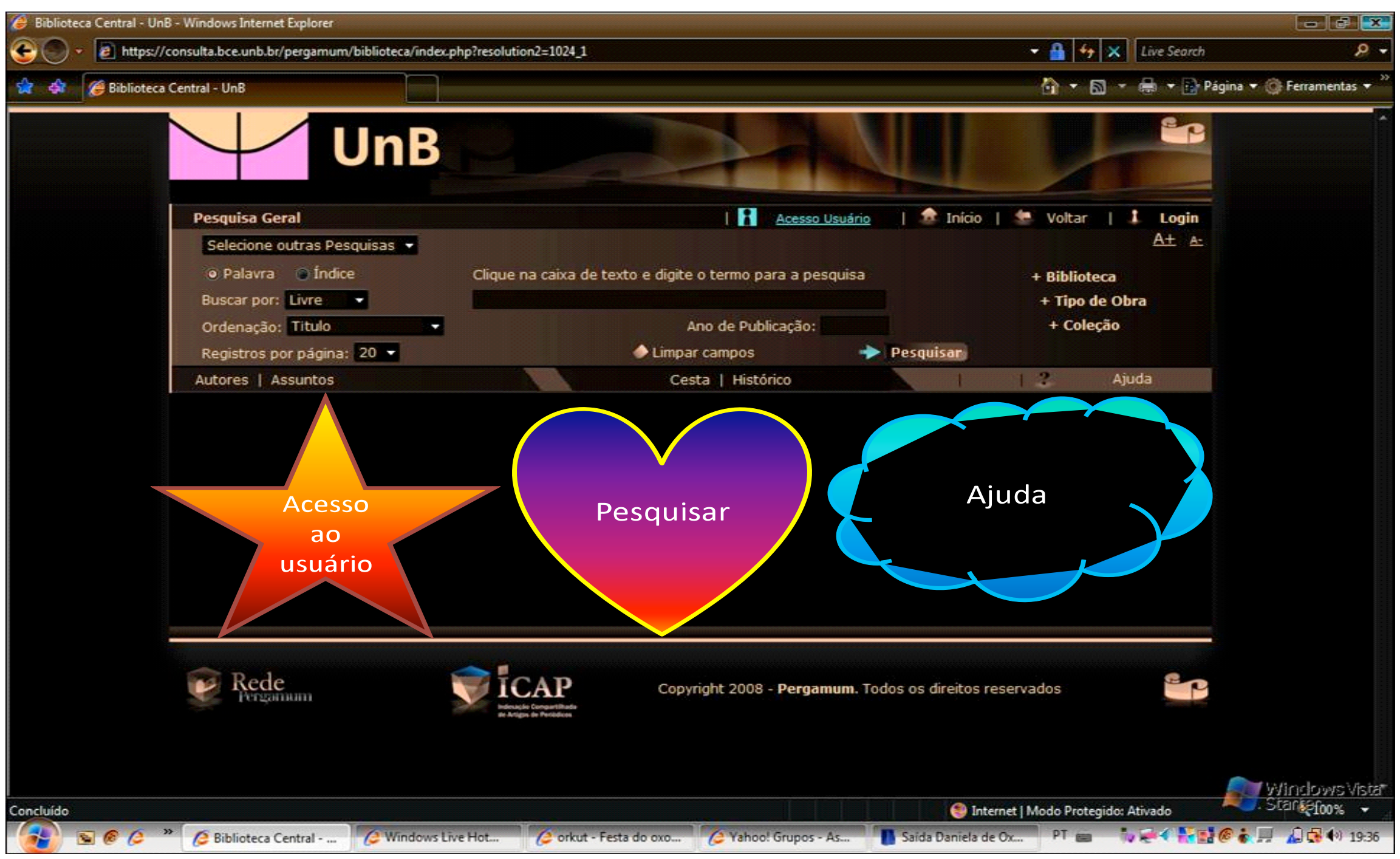


APÊNDICE B - Versão final do protótipo em papel da interface modificada do OPAC da BCE

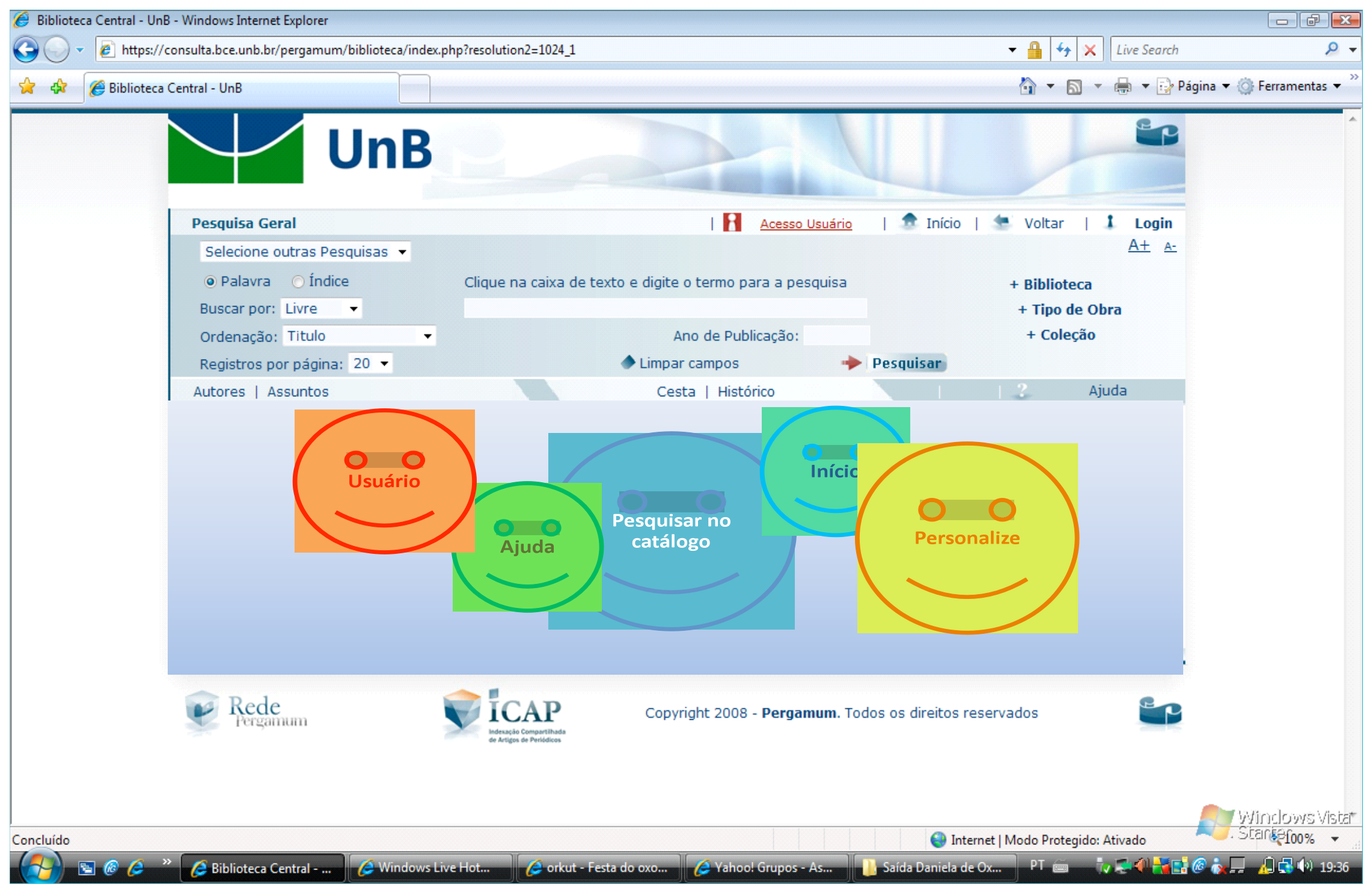


APÊNDICE C - Questionário final aplicado para a interface original do OPAC

Pesquisa para a conclusão do curso de biblioteconomia da Universidade de Brasília, com usuários do catálogo público de acesso em linha da BCE-UnB.

Questionário Final Design Emocional da informação (Interface original)

Aluno: Fábio Marques B. da Silva

1. Diante da interface seu estado afetivo fica?
A. Positivo
B. Negativo
C. Neutro

Por que pensa que ele fica assim?

2. Como você se sente ao ver a interface?
A. Burro;
B. Trapalhão;
C. Irritado;
D. Assustado;
E. Intrigado;
F. Amoroso, dócil, sensibilizado
G. Outro. Como?

Por quê?

3. O que você mudaria na interface? Por quê? 
4. Acha que seria interessante a personalização da interface do catálogo, como a escolha da cor, fonte, tamanho ou poder criar um perfil seu?

5. Você considera que suas emoções diante da interface podem ser mais decisivas para o sucesso dela do que seus elementos práticos? Por quê?

6. Gostaria que a interface fosse mais divertida, brincalhona, como a interface do Google ou que pudesse deixar sua sugestão?

7. O produto satisfaz suas necessidades de busca e recuperação da informação? Se não, por quê?

8. Você considera que a interface foi construída levando em conta o modelo mental do usuário de busca por informação ou o modelo de um especialista? Por quê?

9. O catálogo público de acesso em linha tem um bom desempenho (usabilidade), sentese confortável ao operá-lo? 
APÊNDICE D - Questionário final aplicado para a versão final do protótipo em papel da interface modificada do OPAC da BCE.

Pesquisa para a conclusão do curso de biblioteconomia da Universidade de Brasília, com usuários do catálogo público de acesso em linha da BCE-UnB.

Questionário final de Design Emocional da informação (interface modificada)

Aluno: Fábio Marques B. da Silva

1 - Diante da interface modificada, como se sente?

E seu estado afetivo fica como?
A. Positivo
B. Negativo
C. Neutro

Por quê?

2 - O que você considera como negativo em uma interface? Dê exemplos.

3 - O que o atrairia a utilizá-la levando em conta a aparência da tela? Dê exemplos.

4 - O que você faria para a interface ser mais interativa e divertida? 
5- De exemplos de interfaces de sites que você ama ou odeia? (Se possível coloque o endereço da página)

Tente relatar o porquê de amar ou odiar.

6 - Gostaria que o site se adaptasse às datas correntes com imagens, por exemplo, diabinhos na tela no dia das bruxas, ou gorros de neve no inverno?

7 - Gostaria de dar sugestões periódicas para a escolha de futuras imagens?

8 - E que essas imagens fossem hiperlinks para as partes mais usadas no catálogo? Exemplo: a ajuda; o acesso ao usuário; a pesquisa avançada

9- Que adjetivo atribuiria aos três aspectos da interface sugerida?

Aparência da tela: a)Boa b) Ruim

Usabilidade das imagens no catálogo: a) Boa b) Ruim

Qualidade das lembranças ou associações que ele te traz: a) Boa b)Ruim 


\section{Anexo}

ANEXO A - Interface original do OPAC da BCE

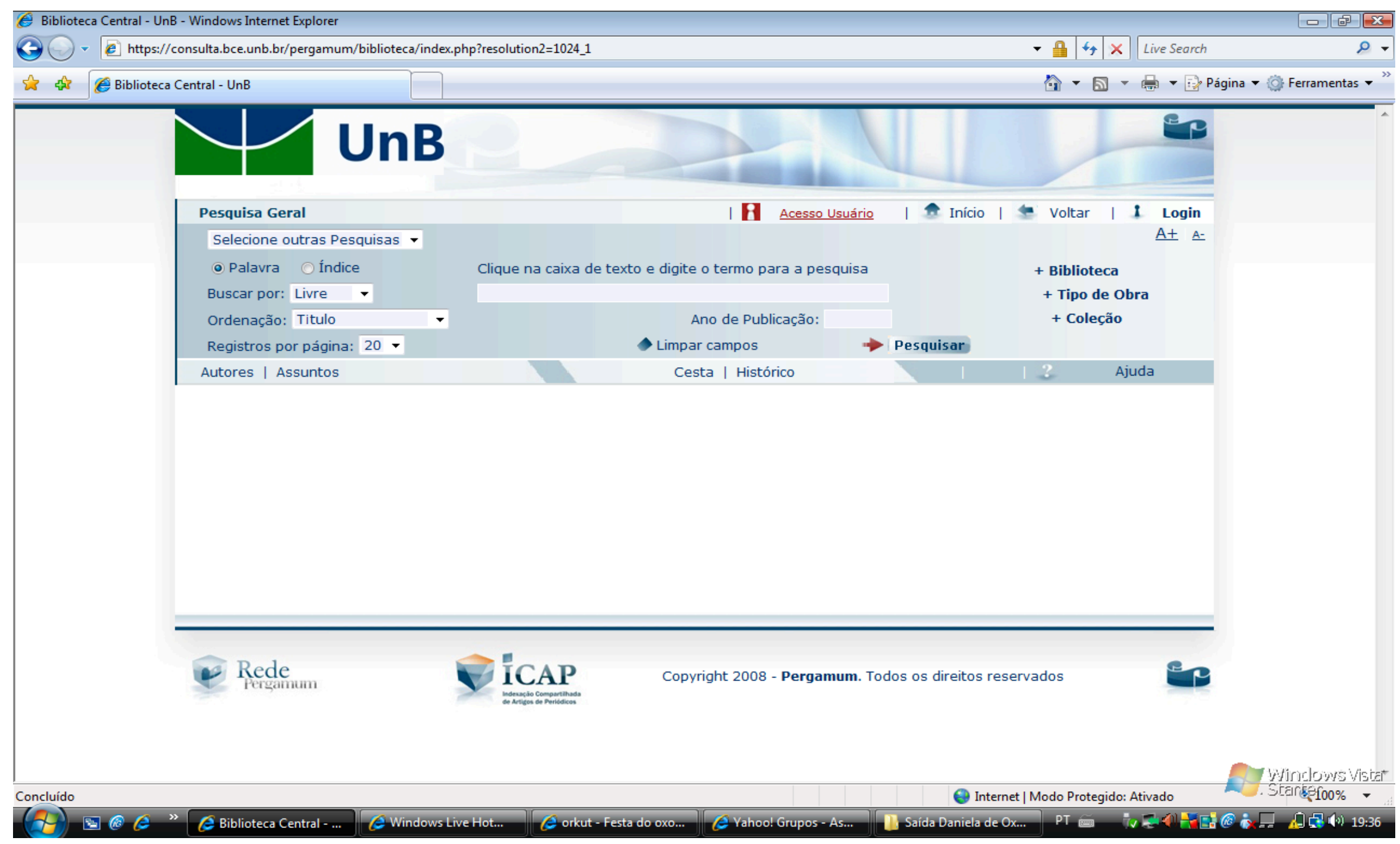

